\title{
National Emission Standards for Hazardous Air Pollutants Calendar Year 2001
}

\author{
June 2002
}

U.S. Department of Energy

National Nuclear Security Administration Nevada Operations Office

Las Vegas, Nevada 


\section{DISCLAIMER}

Reference herein to any specific commercial product, process, or service by trade name, trademark, manufacturer, or otherwise, does not necessarily constitute or imply its endorsement, recommendation, or favoring by the U.S. Government or any agency thereof or its contractors or subcontractors.

This report has been reproduced directly from the best available copy.

Available for sale to the public from:

U.S. Department of Commerce

National Technical Information Service

5285 Port Royal Road

Springfield, VA 22161-0002

Telephone: (800) 553-6847

Fax: (703) 605-6900

E-mail: orders@ntis.fedworld.gov

Online ordering: http://www.ntis.gov/ordering.htm

Available electronically at http://www.osti.gov/bridge.

Available for a processing fee to the U.S. Department of Energy and its contractors, in paper, from:

U.S. Department of Energy

Office of Scientific and Technical Information

P.O. Box 62

Oak Ridge, TN 37831-0062

Telephone: (865) 576-8401

Fax: (865) 576-5728

E-mail: reports@adonis.osti.gov 


\title{
National Emission Standards for Hazardous Air Pollutants Calendar Year 2001
}

\author{
By \\ Robert F. Grossman \\ Edited By \\ Yvonne E. Townsend
}

June 2002

\section{Work Performed Under Contract No. \\ DE-AC08-96NV11718}

\section{Prepared by:}

Bechtel Nevada

Post Office Box 98521

Las Vegas, Nevada 89193-8521 
This page intentionally left blank 


\section{TABLE OF CONTENTS}

$\underline{\text { Page }}$

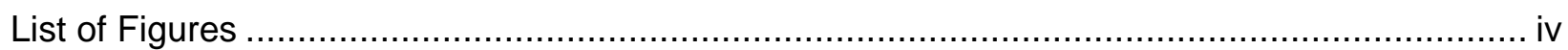

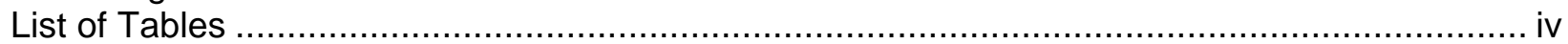

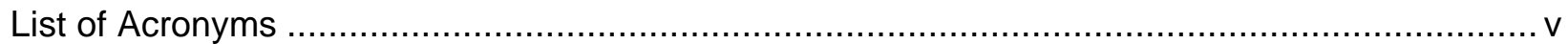

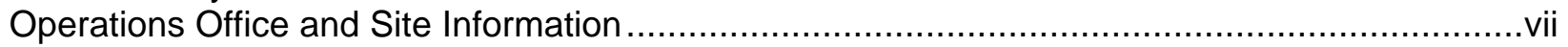

Section I

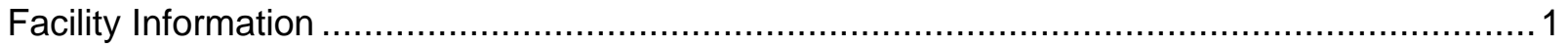

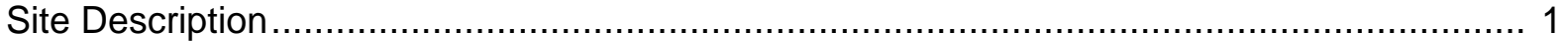

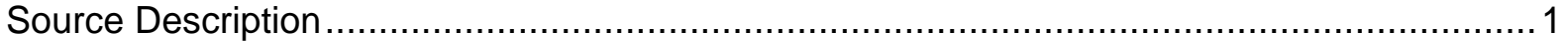

Section II

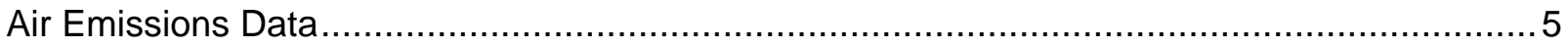

Section III

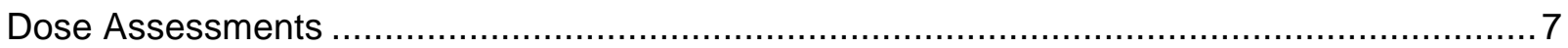

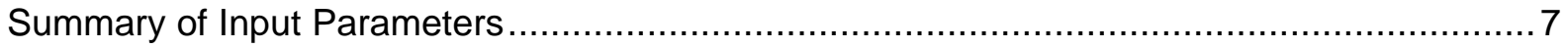

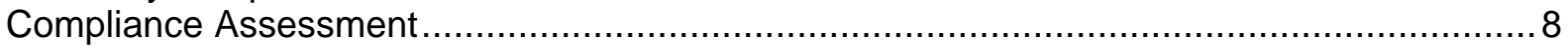

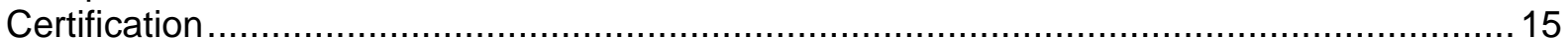

Section IV

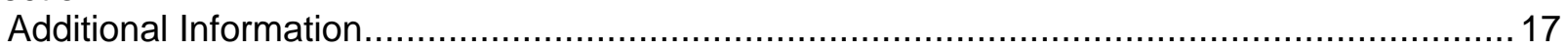

New Construction/Modification Activities at the NTS ................................................ 17

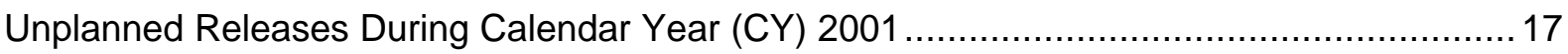

Sources of Diffuse or Fugitive Emissions.......................................................... 17

\section{LIST OF APPENDICES}

Appendix A Public Dose Calculations for the Atlas Tritium Incident................................ A-1

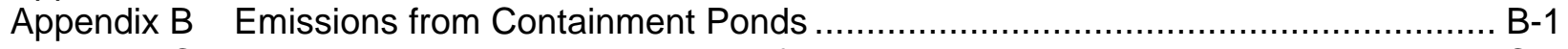

Appendix C Potential Radionuclide Emissions from Radioanalytical Laboratories ................. C-1

Appendix D Atmospheric Tritium Emissions from Diffuse Sources .................................. D-1

Appendix E Resuspended Americium and Plutonium from Yucca Flat and other Areas ........ E-1

Appendix F Identification and Justification for the Development of Meteorological

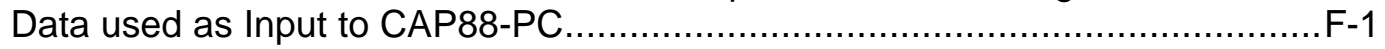

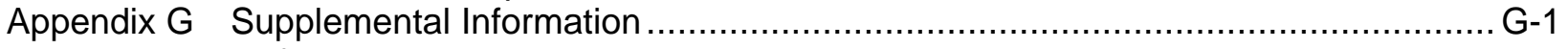

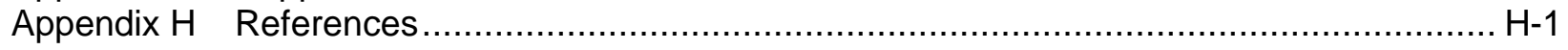

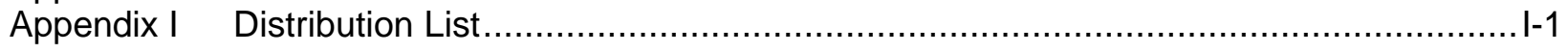




\section{LIST OF FIGURES}

Page

Figure 1.0 Map of the Nevada Test Site and Surrounding Areas .................................. 19

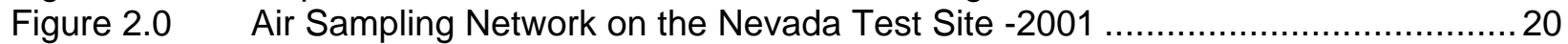

Figure $3.0 \quad$ Photograph of E Tunnel Containment Ponds...............................................21

Figure 4.0 SCHOONER Air Sampling Compliance Station ........................................ 22

Figure F.1 Location of Meteorological Data Acquisition System (MEDA)

Stations on the NTS -2001

\section{LIST OF TABLES}

Table 1.0 Inventory of ${ }^{238} \mathrm{Pu},{ }^{239+240} \mathrm{Pu}$, and ${ }^{241} \mathrm{Am}$ in Surface Soil $(0$ to $5 \mathrm{~cm})$

at Studied Sites

Table 2.0 Summary of Annual Air Emissions Data by Source ${ }^{(a)}$ (Multiply Ci by 37

to obtain $\mathrm{GBq}$ ).

Table 3.0

Table 4.0

Total Estimated Emissions for CY 2001 (Multiply Ci by 37 to obtain GBq)...

Summary of CY 2001 CAP88-PC Calculations of EDE to the MEI Offsite at Springdale, Nevada ${ }^{(a)}$

Table 5.0

Calculated EDEs (ì rem/yr)

Table 6.0

Measured Radionuclide Concentrations at Compliance Air

Sampling Locations.

Table 7.0

Comparison of CAP88-PC Concentrations with Measured Concentrations

at Compliance Stations

Table D.1

Airborne Tritium Sampling Results During CY - 2001

Table E.1

Calculated Emissions from inventories ${ }^{(a)}$ of Plutonium and Americium in NTS Areas

Table G.1

The Maximum Collective EDE to the Population within $80 \mathrm{~km}$ of the NTS 


\section{LIST OF ACRONYMS}

\begin{tabular}{|c|c|}
\hline ARL/SORD & Air Resources Laboratory Special Operations and Research Division \\
\hline ASL & Analytical Services Laboratory \\
\hline BN & Bechtel Nevada \\
\hline CAP88-PC & Clean Air Package 1988 (EPA software program for estimating doses) \\
\hline $\mathrm{Ci}$ & Curie \\
\hline CFR & Code of Federal Regulations \\
\hline CY & Calendar Year \\
\hline DAF & Device Assembly Facility \\
\hline DCG & Derived Concentration Guide \\
\hline DOE & U.S. Department of Energy \\
\hline DRA & Desert Rock Meteorological Observatory \\
\hline EDE & Effective Dose Equivalent \\
\hline EPA & U.S. Environmental Protection Agency \\
\hline ERDA & Energy Research and Development Administration \\
\hline FFACO & Federal Facilities Agreement and Consent Order \\
\hline HTO & Tritiated Water \\
\hline JASPER & Joint Actinide Shock Physics Experimental Research \\
\hline LLW & Low-level Radioactive Waste \\
\hline MDC & Minimum Detectable Concentration \\
\hline MEDA & Meteorological Data Acquisition System \\
\hline $\mathrm{MEI}$ & Maximally Exposed Individual \\
\hline MIDNET & Meteorological Data Network \\
\hline NAFR & Nellis Air Force Range \\
\hline NESHAP & National Emission Standard for Hazardous Air Pollutants \\
\hline NLVF & North Las Vegas Facility \\
\hline NNSA/NV & $\begin{array}{l}\text { U.S. Department of Energy, National Nuclear Security Administration Nevada } \\
\text { Operations Office }\end{array}$ \\
\hline NOAA & National Oceanic and Atmospheric Administration \\
\hline NTS & Nevada Test Site \\
\hline RWMS & Radioactive Waste Management Site \\
\hline RWMS-3 & Radioactive Waste Management Site, Area 3 \\
\hline RWMS-5 & Radioactive Waste Management Site, Area 5 \\
\hline SNM & Special Nuclear Material \\
\hline STAR & Stability Array - (grouping of meteorological data) \\
\hline TRU & Transuranic - (nuclides with atomic numbers greater than uranium) \\
\hline UCC & Yucca Flat Meteorological Observatory \\
\hline
\end{tabular}


This page intentionally left blank 


\section{U.S. Department of Energy \\ National Nuclear Security Administration \\ Nevada Operations Office \\ Air Emissions Annual Report \\ (under Subpart H, Title 40 Code of Federal Regulations [CFR] 61.94) \\ Calendar Year (CY) 2001}

Site Name: Nevada Test Site

\section{Operations Office Information}

Office: $\quad$ U.S. Department of Energy, National Nuclear Security Administration Nevada Operations Office

Address: $\quad$ P. O. Box 98518

Las Vegas, NV 89193-8518

Contact: $\quad$ Kenneth A. Hoar $\quad$ Phone: (702) 295-1428

Director, Environment, Safety and Health Division

\section{Site Information}

Operator: $\quad$ Bechtel Nevada

Address: $\quad$ P. O. Box 98521

Las Vegas, NV 89193-8521

Contact: Wayne F. Johnson Phone: (702) 295-0473

$\underline{\text { Assistant General Manager, Environmental Management }}$ 
This page intentionally left blank 


\section{SECTION I FACILITY INFORMATION}

\section{SITE DESCRIPTION}

The Nevada Test Site (NTS) is operated by the U.S. Department of Energy (DOE), National Nuclear Security Administration Nevada Operations Office (NNSA/NV) as the site for nuclear weapons testing, now limited to readiness activities, experiments in support of the national Stockpile Stewardship Program, and the activities listed below. Located in Nye County, Nevada, the site's southeast corner is about $88 \mathrm{~km}(55 \mathrm{mi})$ northwest of the major population center, Las Vegas, Nevada. The NTS covers about $3,561 \mathrm{~km}^{2}\left(1,375 \mathrm{mi}^{2}\right)$, an area larger than Rhode Island. Its size is 46 to $56 \mathrm{~km}$ ( 28 to $35 \mathrm{mi}$ ) east to west and from 64 to $88 \mathrm{~km}$ (40 to $55 \mathrm{mi}$ ) north to south. The NTS is surrounded, except on the south side, by public exclusion areas (Nellis Air Force Range [NAFR]) that provide another 24 to $104 \mathrm{~km}$ (15 to $65 \mathrm{mi}$ ) between the NTS and public lands (Figure 1.0). The NTS is characterized by desert valley and Great Basin mountain topography, with a climate, flora, and fauna typical of the southwest deserts. Population density within $150 \mathrm{~km}$ (93 mi) of the NTS is only about 0.2 persons per square kilometer, excluding the Las Vegas area. Restricted access, low population density in the surrounding area, and extended wind transport times are advantageous factors for the activities conducted at the NTS. Surface waters are scarce on the NTS, and slow-moving groundwater is present hundreds to thousands of feet below the land surface.

\section{SOURCE DESCRIPTION}

The sources of radionuclides include current and previous activities conducted on the NTS (Figure 2.0). The NTS was the primary location for testing of nuclear explosives in the Continental U.S. between 1951 and 1992. Historical testing above or at ground surface has included (1) atmospheric testing in the 1950s and early 1960s, (2) earth-cratering experiments, and (3) open-air nuclear reactor and rocket engine testing. Since the mid-1950s, testing of nuclear explosive devices has occurred underground in drilled vertical holes or in mined tunnels (DOE 1996a). No such tests have been conducted since September 23, 1992 (DOE 2000). Limited non-nuclear testing includes spills of hazardous materials at the Hazardous Materials Spill Center, private technology development, aerospace and demilitarization activities, and site remediating activities. Processing of radioactive materials is limited to laboratory analyses, and handling is restricted to transport, storage, and assembly of nuclear explosive devices and operation of radioactive waste management sites (RWMSs) for low-level radioactive and mixed waste (DOE 1996a). Monitoring and evaluation of the various activities conducted onsite indicate that the potential sources of offsite radiation exposure in CY 2001 were releases from (1) evaporation of tritiated water (HTO) from containment ponds that receive drainage water from $\mathrm{E}$ Tunnel in Area 12 and from discharges of two wells (Well U-3cn PS\#2 and Well ER-20-5 \#3) into lined ponds, (2) onsite radioanalytical laboratories, (3) the Area 5 RWMS (RWMS-5) facility, and (4) diffuse sources of tritium and re-suspension of plutonium and americium. The following sections present a general description of the present sources on the NTS and at the North Las Vegas Facility.

At the North Las Vegas Facility (NLVF), operated for NNSA/NV by Bechtel Nevada (BN), there was an unusual occurrence in 1995 that led to a very small potential exposure to an offsite person. The incident involved the release of tritium as HTO. The HTO emission has continued at lower levels (probably re-emanation from building materials), even after cleanup activities in November and December 1997. A description of the incident and the method of calculating the effective dose equivalent (EDE) for offsite exposure are set forth in Appendix $A$. 


\section{Tunnel Operations}

Nuclear explosive tests have been conducted within tunnel complexes mined into the Rainier Mesa region and in Areas 15 and 16. When these tests were conducted, purging gases from the tunnel occasionally resulted in releases of radioactivity, and contaminated water drained from the tunnels into containment ponds (Energy Research and Development Administration [ERDA] 1977). No testing activities have occurred since 1992.

\section{Containment Ponds}

Water contaminated with radionuclides seeped from the tunnels in Area 12 and was collected in containment ponds resulting in water evaporation and seepage into the soil. The tunnels have been sealed, but water continues to seep from $E$ Tunnel. A photograph of the tunnel containment ponds at $E$ Tunnel is provided in Figure 3.0. The only radiological contaminant which produces a measurable air emission from evaporation of the water is ${ }^{3} \mathrm{H}$ (as HTO). Calculation of the source term for this emission is described in Appendix B.

To characterize the groundwater regime under the NTS, suitable wells are being drilled and existing wells re-completed in the vicinity of certain underground tests and at other locations on the NTS, as determined by hydrologists. During these drilling operations, contaminated water is pumped from the wells and diverted to lined containment ponds if the tritium level exceeds $2 \times 10^{5} \mathrm{pCi} / \mathrm{L}$, as required by the state and explained in the Underground Test Area Program (DOE 1996a). During CY 2001, this was done at Well U-3cn PS\#2 (Area 3) and Well ER-20-5 \#3 (Area 20). The estimated emissions from these activities are also explained in Appendix B.

Water contaminated primarily with tritium is sometimes pumped from Well RMNS-2 into the Area 5 CAMBRIC ditch as part of special studies. However, during CY 2001 no studies were conducted.

\section{Laboratories}

Radiological analyses were conducted in laboratories located in Building 652 (Mercury); Building CP-95A (Area 6); and the Device Assembly Facility (DAF) (Area 6). Because these facilities process environmental samples, very little radioactivity passes through them. However, there is potential for some radionuclides to be discharged into the atmosphere from the hood ventilation systems during sample processing, particularly of spiked samples, or from loss of radioactive standards in liquid or gaseous form. In the past, evaporation and spills from samples containing HTO, radioiodines, or noble gases were conservatively estimated by assuming all such materials were released, although they were not. This year only actual emissions are reported, such as 5.6 curies (Ci) of tritium gas which was used periodically during the year at Area 6 CP-50 to calibrate analytical equipment. The source terms for these laboratories and the EDE resulting from the 5.6 Ci emission is described in Appendix C.

Non-volatile radioactive standards were controlled by keeping their inventory below the possession limits set forth in Title 40 Code of Federal Regulations (CFR) 61 (CFR 2002).

\section{Radioactive Waste Management Sites}

The RWMSs in Area 3 (RWMS-3) and in Area 5 (RWMS-5) are used for the disposal of low-level radioactive waste (LLW). The RWMS-5 is also used for accumulation of mixed waste and storage of transuranic (TRU) and mixed TRU wastes. Disposal is accomplished by the use of pits and trenches. Concrete pads are used for temporary storage of certain wastes.

At RWMS-5, only packaged, dry wastes are accepted for disposal. The facility is considered a diffuse source of radiological effluents. The only radioactive emission detected by the various types of samplers surrounding the site and attributed to site operations was HTO in atmospheric 
moisture. The calculation of the HTO source term for these emissions is explained in Appendix D. Since the RWMS-3 LLW site is in a location where the surrounding surface soil has been contaminated by past nuclear tests, the re-suspension of this soil by wind or vehicular activity results in above background levels of plutonium being detected in air samples collected inside and outside the perimeter fence.

\section{Joint Actinide Shock Physics Experimental Research (JASPER)}

The construction and startup phase for a hydrogen gas gun in Building 5100 in Area 27 was completed in June 2000. Equation-of-state experiments with the two-stage light gas gun will be conducted under the Project JASPER Facility using special nuclear materials (SNM) and other actinide materials as target material. Approval by the U.S. Environmental Protection Agency (EPA) has been obtained for the project, and a stack monitoring system was installed to assure that the experimental emissions are in conformance with National Emission Standards for Hazardous Air Pollutants (NESHAPs) once operations with radioactive materials begin. During CY 2001, an integrated testing program using only surrogate materials (non-SNMs) was conducted; no radioactive materials were used.

\section{Surface Areas Contaminated with Tritium, Plutonium, or Americium}

Tritium emanation from the cratering tests SEDAN and SCHOONER was detectable in atmospheric moisture samples collected on molecular sieves by special air samplers. Derivation of the source terms for these locations is described in Appendix D.

Surface soils in certain areas on and off of the NTS were contaminated with plutonium and/or tritium from either nuclear device safety, atmospheric, or cratering tests, using nuclear explosives. An investigation of these areas during the Nevada Applied Ecology Group studies, updated by the Desert Research Institute (DOE 1991), developed the inventories of plutonium shown in Table 1.0. These areas could become sources of exposures to americium and plutonium if the contaminated soils were to be re-suspended, e.g., during windy conditions, surface cleanup, construction, vehicular travel, or similar activities. Figure 2.0 is a map showing the approximate locations of the nuclear tests on or near the NTS. There are air samplers at or near most of these onsite areas. Analyses of the glass-fiber filters from these samplers indicate that the majority of the plutonium results are less than the minimum detectable concentration (MDC), and in most detectable cases are less than the two standard deviation (2s) counting error. The results $>$ MDC are usually from air samplers in areas where operational activities can cause contaminated surface soil to become re-suspended. These areas are considered diffuse sources of radioactive effluents resulting in the detection of americium and plutonium in the majority of air samples collected at nearby locations. The derivation of the source term for and the reason for selection of americium and plutonium from contaminated areas is explained in Appendix $E$.

\section{Federal Facilities Agreement and Consent Order (FFACO)}

Under the FFACO between DOE/NV (now NNSA/NV) and the state (FFACO 1996), contamination generated by historical NTS activities is being addressed. Two surface areas on the NAFR have had partial source removal, resulting in a decrease in the offsite EDE. These surface areas are DOUBLE TRACKS remediated in 1996 and CLEAN SLATE I in 1997. The monitoring plan for such activities required continuous air sampling before, during and after cleanup operations until the concentration in air returned to background levels. The clean up of DOUBLE TRACKS (DOE 1997a) and CLEAN SLATE I (DOE 1997b) areas resulted in the removal of $5.12 \mathrm{Ci}$ and $5.65 \mathrm{Ci}$ of ${ }^{239+240} \mathrm{Pu}$, respectively, based upon radiation measurements of the soil as it was bagged for transporting to burial in the RWMS-3. The amounts removed are within the 95 percent confidence interval of the 1.7 to $6.0 \mathrm{Ci}$ estimated for each of these two locations. 
Table 1.0 Inventory of ${ }^{238} \mathrm{Pu},{ }^{239+240} \mathrm{Pu}$, and ${ }^{241} \mathrm{Am}$ in Surface Soil $(0$ to $5 \mathrm{~cm})$ at Studied Sites

\begin{tabular}{|c|c|c|c|c|}
\hline \multicolumn{5}{|c|}{ Oncito Arase Sturdiod (a) } \\
\hline Area & Area $\left(\mathrm{mi}^{2}\right)$ & ${ }^{241} \mathrm{Am}(\mathrm{Ci})$ & ${ }^{238} \mathrm{Pu}(\mathrm{Ci})$ & ${ }^{239} \mathrm{Pu}(\mathrm{Ci})$ \\
\hline 1 & 26.5 & 4.2 & 6.5 & $24^{(\mathrm{b})}$ \\
\hline 2 & 19.7 & 2.9 & 8.6 & $22^{(\mathrm{b})}$ \\
\hline 3 & 32.3 & 4.6 & 3.1 & 37 \\
\hline 4 & 16.0 & 6.6 & 13 & $40^{(\mathrm{b})}$ \\
\hline 5 & 2.9 & 0.6 & 0.1 & $4.8^{(b)}$ \\
\hline 6 & 32.3 & 1.7 & 3.3 & $8.4^{(\mathrm{b})}$ \\
\hline 7 & 19.3 & 2.2 & 0.6 & $16^{(\mathrm{b})}$ \\
\hline 8 & 13.9 & 17 & 8.0 & 110 \\
\hline 9 & 20.0 & 4.2 & 2.2 & 89 \\
\hline 10 & 20.0 & 19 & 19 & 110 \\
\hline 11 & 4.0 & 3.3 & 0.5 & 29 \\
\hline 12 & 39.6 & 5.7 & 8.5 & $39^{(b)}$ \\
\hline 15 & 35.3 & 8.0 & 7.8 & $63^{(b)}$ \\
\hline 16 & 14.3 & 0.7 & 1.5 & $3.7^{(b)}$ \\
\hline 17 & 31.4 & 2.8 & 4.5 & $18^{(b)}$ \\
\hline 18 & 27.3 & 19 & 5.6 & 100 \\
\hline 19 & 148.3 & 21 & 32 & $140^{(b)}$ \\
\hline 20 & 6.2 & 23 & 30 & 41 \\
\hline 25 & 0.9 & 0 & 0 & 0 \\
\hline 26 & 0.2 & 0 & 0 & 0 \\
\hline 30 & 0.3 & 3.2 & 4.5 & $14^{(\mathrm{b})}$ \\
\hline \multicolumn{5}{|c|}{ Offsite Areas Studied (c) } \\
\hline Area 13 & 1.55 & $\mathrm{~N} / \mathrm{A}$ & $\mathrm{N} / \mathrm{A}$ & 46 \\
\hline CLEAN SLATE II & 0.18 & $\mathrm{~N} / \mathrm{A}$ & $\mathrm{N} / \mathrm{A}$ & 17 \\
\hline CLEAN SLATE III & 0.67 & $\mathrm{~N} / \mathrm{A}$ & $\mathrm{N} / \mathrm{A}$ & 37 \\
\hline
\end{tabular}

N/A Not available.

(a) (DOE 1991).

(b) The above referenced report indicated that these levels were probably the result of fallout from nuclear tests in surrounding areas.

(c) Storage-transportation tests of nuclear devices (DOE 1992). 


\section{SECTION II AIR EMISSIONS DATA}

Each potential source of NTS emissions was characterized by one of the following methods:

(1) monitoring methods and procedures previously developed at the NTS; (2) a yearly radionuclide inventory of the sources in laboratories, identifying any volatile radionuclides that were released to the environment; (3) the measurement of tritiated water concentrations in liquid effluents discharged to containment ponds and assuming all the effluent evaporates over the course of the year to become an air emission; (4) use of re-suspension calculations; and (5) using a combination of environmental measurements and the Clean Air Package 1988 air dispersion model (CAP88-PC) (EPA 1992) to calculate emissions. Appendices A through E describe the methods used to determine the emissions from the sources listed in Table 2.0. In accordance with Title 40 CFR 61.93.(b)(4), (CFR 2002) no credit was taken for pollution control equipment in determining air emissions.

The emissions for NESHAPs reporting are listed in Table 2.0. These emissions are very conservative (worst-case) and are used in Section III to calculate the EDE to the maximally exposed individual (MEI) offsite.

Table 2.0 Summary of Annual Air Emissions Data by Source ${ }^{(a)}$ (Multiply Ci by 37 to obtain GBq)

\begin{tabular}{||l|c|c|c|c||}
\hline \multicolumn{1}{|c|}{ Source Type } & $\begin{array}{c}\text { Type of } \\
\text { Control }\end{array}$ & $\begin{array}{c}\text { Distance to } \\
\text { Nearest Receptor }\end{array}$ & Nuclide & Quantity (Ci) \\
\hline \hline Point Sources & & & & \\
CP-50, Area 6 & None & $42 \mathrm{~km}$ & ${ }^{3} \mathrm{H}$ & 5.6 \\
Building A-1 & (a) & $0.1 \mathrm{~km}$ & ${ }^{3} \mathrm{H}$ & 0.20 \\
Area Sources & None & & & \\
E Tunnel ponds & None & $50 \mathrm{~km}$ & ${ }^{3} \mathrm{H}^{(\mathrm{b})}$ & 14 \\
RWMS-5 & None & $36 \mathrm{~km}$ & ${ }^{3} \mathrm{H}^{(\mathrm{c})}$ & 3.4 \\
SCHOONER & None & $20 \mathrm{~km}$ & ${ }^{3} \mathrm{H}^{(\mathrm{c})}$ & 270 \\
SEDAN & None & $50 \mathrm{~km}$ & ${ }^{3} \mathrm{H}^{(\mathrm{c})}$ & 270 \\
Well U-3cn PS\#2 & None & $56 \mathrm{~km}$ & ${ }^{3} \mathrm{H}^{(\mathrm{b})}$ & 0.94 \\
Well ER-20-5 \#3 & None & $28 \mathrm{~km}$ & ${ }^{3} \mathrm{H}^{(\mathrm{b})}$ & 0.016 \\
Grouped Area Sources & & & & \\
All NTS Areas & None & $20-60 \mathrm{~km}$ & ${ }^{241} \mathrm{Am}^{(\mathrm{d})}$ & $4.7 \times 10^{-2}$ \\
& None & $20-60 \mathrm{~km}$ & ${ }^{239+240} \mathrm{Pu}^{(\mathrm{d})}$ & $2.9 \times 10^{-1}$ \\
Near Offsite & None & $38-43 \mathrm{~km}$ & ${ }^{241} \mathrm{Am}^{(\mathrm{d})}$ & $2.0 \times 10^{-3}$ \\
& None & $38-43 \mathrm{~km}$ & ${ }^{239+240} \mathrm{Pu}^{(\mathrm{d})}$ & $3.2 \times 10^{-2}$ \\
\hline
\end{tabular}

(a) All locations at or near the NTS except Building A-1, which is in North Las Vegas.

(b) Emission based on tritiated water discharged into containment pond(s).

(c) Emission based on environmental surveillance results and CAP88-PC software.

(d) Emission estimated from resuspension model and CAP88-PC software. 
A summary of the NTS total CY 2001 emissions for NESHAP's reporting, by radionuclide, is provided in Table 3.0.

Table 3.0 Total Estimated NTS Emissions for CY 2001 (Multiply Ci by 37 to obtain GBq)

\begin{tabular}{||l|c|}
\hline Radionuclide & Annual Quantity (Ci) \\
\hline \hline${ }^{3} \mathrm{H}$ & 564 \\
${ }^{241} \mathrm{Am}$ & $4.9 \times 10^{-2}$ \\
${ }^{239+240} \mathrm{Pu}$ & $3.2 \times 10^{-1}$ \\
\hline
\end{tabular}

Note: This table includes all worst-case point and diffuse source releases. 


\section{SECTION III DOSE ASSESSMENTS}

\section{SUMMARY OF INPUT PARAMETERS}

CAP88-PC was used to calculate EDEs to offsite residents. The input parameters were the annual radionuclide emissions listed in Section II as determined from effluent monitoring performed by the contractor, evaporation of HTO, and calculations of diffuse source emissions that are based on environmental monitoring data and plutonium/americium re-suspension. All emissions were assumed to occur gradually through the year.

The estimated release of tritium from Building A-1 at the NLVF was calculated from measurements of tritium in atmospheric moisture samples collected in the basement area in December 2000 and January 2001 and the flow rate of the air ventilated from the basement. A detailed description is given in Appendix $A$.

The amount of HTO evaporated from ponds was calculated from measurements of HTO concentration and water volume discharged into the containment ponds. A description of the source term estimated for this emission source is contained in Appendix B.

The inventories of gaseous or liquid radioactive sources used by the NTS laboratories were reviewed to determine if any had contributed to emissions during CY 2001. Only one source was identified, a tank of tritium gas, which contained $5.6 \mathrm{Ci}$. It was assumed that this gas was gradually released over the year. Appendix $C$ provides additional details of the source inventories, the estimated emission, and the calculations used for estimating the EDEs to offsite residents.

Several diffuse sources of tritium from past nuclear tests are located at the NTS. The annual source term of such emissions was estimated from environmental air samples collected near the sites of these sources and CAP88-PC calculations. Appendix D explains the methodology and results.

The source terms from the re-suspension of americium $\left({ }^{241} \mathrm{Am}\right)$ and plutonium $\left({ }^{239+240} \mathrm{Pu}\right)$ deposited on soil from past nuclear testing were calculated from a re-suspension model (NRC 1983) and the radionuclide inventory of ground-surface contamination listed in Table 1.0 (DOE 1991; DOE 1992). Appendix E describes the application of the model and the resulting emission source terms for americium and plutonium for each area are listed in Table E.1. Dose assessments did not include ${ }^{238} \mathrm{Pu}$ because air sampling results in the past have shown that most of the concentrations in air have been below the minimum detectable concentration.

The individual source terms, whose sums are listed in Table 2.0, were used with five stability array (STAR) data files as input to CAP88-PC. The five STARs for the NTS include the files with names NTSYUCCA, AREA05, MEDA20, DESERTRK, and T TUNNEL. NTSYUCCA is used for sources on Yucca Flat (Areas 1, 2, 3, 4, 6, 7, 8, 9, 10, and 18); AREA05 is used for sources in Area 5, which includes Frenchman Flat; DESERTRK is used for sources in Mercury; MEDA20 is used for sources in Areas 19 and 20; and T TUNNEL for the tunnel pond sources in Area 12. MEDA20, T TUNNEL, and AREA05 were developed by the Air Resources Laboratory, Special Operations and Research Division (ARL/SORD), using data obtained from the meteorological stations located near the boundary of Areas 19 and 20 on Pahute Mesa, near the tunnels in 
Area 12, and at Well 5B in Area 5. The other two files were provided by the National Climatic Data Center in North Carolina, based on data from meteorological stations in Yucca Flat and at Desert Rock Meteorological Observatory (DRA). The ARL/SORD assessment is attached as Appendix F. For each of these five STARs there may be a different location for the MEI; but when the contributions of all the NTS sources to a given location are considered, only one location would receive the maximum exposure.

\section{COMPLIANCE ASSESSMENT}

Beginning in July 2001, BN established the following compliance air sampling stations on the NTS (see Figure 2.0):

Area 6, Yucca

Area 10, Gate 700 South

Area 16, Substation 3545

Area 20, SCHOONER

Area 23, Mercury Track

Area 25, Guard Station 510

This initiated a change, approved by EPA Region IX (EPA 2001a), in the method for demonstrating compliance with NESHAPs. Although the compliance air sampling stations are on the NTS, they are to conservatively represent offsite critical receptors. As allowed by 10 CFR Part 61.93(b)(5), the measurement of radionuclide air concentrations at EPA-approved critical receptor locations is an acceptable alternative to using air dispersion calculations with CAP88PC software. Compliance with NESHAPs is demonstrated if the measured concentration of each radionuclide at each of these locations is less than the concentration levels of Table 2 in 40 CFR 61, Appendix E, and the sum of fractions resulting from dividing each measured concentration by the value in Table 2 for each radionuclide is less than one. Since this method was implemented in the middle of the year, the method of estimating radioactive emissions and calculating EDEs to offsite residents with CAP88-PC software was continued for this year to assure that NTS operations are in compliance.

The motivation for this change was that the use of air sampling is a more direct method for assessing compliance with NESHAPs than using an atmospheric diffusion model such as CAP88-PC. As indicated in the proposal submitted to the EPA, monitoring data for air sampling locations near the sources of emissions on the NTS showed that the annual average concentrations of ${ }^{239+240} \mathrm{Pu}$ in 1997 were small fractions of the DCG for an EDE of $10 \mathrm{mrem} / \mathrm{year}$. Subsequent annual site environmental monitoring reports continue to support this finding.

Table 6.0 lists the average radionuclide concentrations and their percentage of the NESHAPs compliance level for each of the compliance stations. All concentration averages were below 1 percent of the compliance levels except for the tritium $\left({ }^{3} \mathrm{H}\right)$ average at the SCHOONER sampler station, which was 27 percent. The average concentration is high at SCHOONER because the air sampler is only $269 \mathrm{~m}$ from the center of the crater and located within the area that received ejecta from the cratering experiment (see Figure 4.0).

Since only one of the six compliance stations (SCHOONER) operated for the full year, an evaluation of the annual concentration averages versus the averages for the July-to- December period was conducted for the other network stations that operated throughout the year to determine whether an adjustment was needed to make six-month averages comparable to annual averages. Statistically significant differences between the annual averages and the JulyDecember averages were observed from the other network station data only for the tritium and 
${ }^{241} \mathrm{Am}$ averages. The average of the ratio (full-year average to July-to-December average) for each of these radionuclides was then determined ( 0.675 and 0.816 , respectively) and multiplied by the July-to-December averages.

To determine how the air concentrations computed by the CAP88-PC software compared to the measured concentrations at the compliance stations, the concentrations of tritium as HTO,

${ }^{241} \mathrm{Am}$, and ${ }^{239+240} \mathrm{Pu}$ at each compliance station were computed by CAP88-PC software for each emission source and summed for each radionuclide and compliance station. The summed concentrations for each radionuclide and each compliance station were divided by the average of the measured concentrations. Usually the conservative assumptions in CAP88-PC predictions result in predictions that are higher than measured values. However, as shown in Table 7.0, the CAP88-PC software predicted concentrations that were lower than the measured concentrations for ${ }^{241} \mathrm{Am}$ and ${ }^{239+240} \mathrm{Pu}$ at Mercury. Also the predicted concentrations for HTO were slightly less than the measured at all compliance stations except for Gate 700 South. This apparent departure from normal expectations of CAP88-PC is attributed to the predicted and measured concentrations being below or near the MDCs of the measurements. At these low levels, the ratio of the values becomes highly variable and indeterminate.

\section{Assessment by Emission Estimates and CAP88-PC Calculations}

The source terms listed in Table 2.0 and Table E.1, for the non-point sources from the resuspension of americium and plutonium, were used as input to CAP88-PC calculations in conjunction with the above mentioned wind files for the appropriate NTS areas to calculate the EDEs to all offsite residents within $80 \mathrm{~km}$ of each emission location. As shown by Table 5.0, the EDEs for each location were summed for all conservatively estimated emissions for the year. The location of the MEl is once again at Springdale, Nevada, where a population of approximately 20 persons each received $0.17 \mathrm{mrem} / \mathrm{yr}$, which is only 1.7 percent of the 10 $\mathrm{mrem} / \mathrm{yr}$ standard of NESHAPs.

Table 4.0 summarizes the contributions to the EDEs from the locations of the emissions and the radionuclide sources for Springdale. As shown by this table, the diffuse tritium sources and the laboratory sources contributed little to the total dose; the re-suspension of americium and plutonium from all areas contributed virtually all of the dose. Appendices $B$ through $E$ contain the methods by which the releases of radionuclides were calculated. Evaporative and re-suspension emissions are also compared to EPA suggested methods as a check on the relative values produced. 
Table 4.0 Summary of CY 2001 CAP88-PC Calculations of EDE to the MEI Offsite at Springdale, Nevada ${ }^{(a)}$

\begin{tabular}{|c|c|c|}
\hline Source & $\begin{array}{l}\text { Distance to Individual } \\
\text { and Direction }\end{array}$ & $\frac{\mathrm{EDE}}{(\mathrm{mrem})^{(\mathrm{b})}}$ \\
\hline \multicolumn{3}{|l|}{ Tritium (diffuse) } \\
\hline Area 3 (Well U-3cn PS\#2) & $65 \mathrm{~km} \mathrm{~W}$ & $1.7 \times 10^{-6(c)}$ \\
\hline Area 5 (RWMS) & $74 \mathrm{~km}$ WNW & $3.9 \times 10^{-5}$ \\
\hline Area 10 (SEDAN) & $65 \mathrm{~km}$ WSW & $5.0 \times 10^{-4}$ \\
\hline Area 12 (E Tunnel Ponds) & $53 \mathrm{~km}$ WSW & $3.0 \times 10^{-5}(\mathrm{c})$ \\
\hline Area 20 (SCHOONER) & 38 km SSW & $3.6 \times 10^{-4}$ \\
\hline Area 20 (Well ER-20-5\#3) & 32 km SW & $\underline{3.5 \times 10^{-8(c)}}$ \\
\hline Subtotal & & $9.3 \times 10^{-4}$ \\
\hline \multicolumn{3}{|l|}{ Laboratories } \\
\hline Area 6 (CP-50) & $64 \mathrm{~km}$ WNW & $\underline{6.4 \times 10^{-6}}$ \\
\hline Subtotal & & $6.4 \times 10^{-6}$ \\
\hline \multicolumn{3}{|l|}{ Re-suspension } \\
\hline Area 3 & $62 \mathrm{~km} \mathrm{~W}$ & $5.7 \times 10^{-3}$ \\
\hline Area 5 & $74 \mathrm{~km}$ WNW & $1.9 \times 10^{-4}$ \\
\hline Area 8 & $62 \mathrm{~km}$ WSW & $1.8 \times 10^{-2}$ \\
\hline Area 9 & $64 \mathrm{~km} \mathrm{~W}$ & $1.2 \times 10^{-2}$ \\
\hline Area 10 & $65 \mathrm{~km}$ WSW & $1.7 \times 10^{-2}$ \\
\hline Areas 18/19/20 & 42 km SW & $7.7 \times 10^{-2}$ \\
\hline All Other Areas & & $\underline{4.2 \times 10^{-2}}$ \\
\hline Subtotal & -- & $1.7 \times 10^{-1}$ \\
\hline Total EDE & & $0.17 \mathrm{mrem}$ \\
\hline
\end{tabular}

(a) Location of residences and communities around the NTS are shown in Figure 1.0.

(b) For mSv, multiply by $10^{-2}$.

(c) Assumes evaporation of all tritiated water influents to ponds. 
Table 5.0 Calculated EDEs ( $\mu \mathrm{rem} / \mathrm{yr}$ )

\begin{tabular}{|c|c|c|c|c|c|c|c|c|c|c|c|c|c|c|c|}
\hline \multirow{3}{*}{ Location } & \multicolumn{15}{|c|}{ EDE ( $\mu \mathrm{rem} / \mathrm{yr})$ due to emissions from: } \\
\hline & Area 1 & Area 2 & Area 3 & Area 4 & Area 5 & Area 6 & Area 7 & Area 8 & Area 9 & Area 10 & Area 11 & $\begin{array}{l}\text { Area } 3 \text { Well } \\
\text { U-3cnPS\#2 }\end{array}$ & $\begin{array}{l}\text { Area } 5 \\
\text { RWMS }\end{array}$ & $\begin{array}{l}\text { Area } 6 \\
\text { CP-50 } \\
\end{array}$ & $\begin{array}{l}\text { Area } 10 \\
\text { SEDAN }\end{array}$ \\
\hline & \multicolumn{11}{|c|}{${ }^{239+240} \mathrm{Pu}$ and ${ }^{241} \mathrm{Am}$} & \multicolumn{4}{|c|}{ Tritium) } \\
\hline ALAMO & & & & & & & & & & 3.9 & & & & & 0.21 \\
\hline AMARGOSA VALLEY & 3 & 3.1 & 4.6 & 6.6 & 0.38 & 1.2 & 1.8 & 15 & 11 & 14 & 3.5 & 0.0016 & 0.038 & 0.12 & 0.46 \\
\hline ASH MEADOWS & 3.3 & & 4.8 & & 0.3 & 1.3 & & & & & 3.9 & 0.0016 & 0.036 & 0.012 & \\
\hline BEATTY & 4 & 3.3 & 5.4 & 6.6 & 0.23 & 1.3 & 2.1 & 15 & 10 & 15 & 3.6 & 0.0016 & 0.043 & 0.011 & 0.46 \\
\hline CACTUS SPRINGS & 1.2 & 1.3 & 3.8 & 1.8 & 1.3 & 1.1 & 1.2 & 6.7 & 5.3 & 7.4 & 3.7 & & 0.05 & 0.007 & 0.45 \\
\hline \multicolumn{16}{|l|}{ CLARK STATION } \\
\hline CORN CREEK STA. & & & & & 0.34 & & & & & & 0.91 & & 0.032 & & \\
\hline CRYSTAL & 3.2 & 2.3 & 6.7 & 4.9 & 0.82 & 2.2 & 1.8 & 11 & 8.3 & 11 & 6.7 & 0.0019 & 0.043 & 0.016 & 0.38 \\
\hline DEATH VALLEY JCT. & & & & & 0.22 & & & & & & & & 0.031 & 0.011 & \\
\hline \multicolumn{16}{|l|}{ FURNACE CREEK } \\
\hline \multicolumn{16}{|l|}{ GOLDFIELD } \\
\hline \multicolumn{16}{|l|}{ HIKO } \\
\hline INDIAN SPRINGS & 1.1 & 1.3 & 3 & 1.8 & 1.3 & 0.64 & 1.2 & 6.6 & 5.3 & 6.9 & 3.8 & 0.0018 & 0.046 & 0.0066 & 0.43 \\
\hline LATHROP WELLS & 6.9 & 4 & 7.6 & 10 & 0.71 & 2.2 & 2.9 & 19 & 14 & 19 & 5.8 & 0.002 & 0.049 & 0.015 & 0.52 \\
\hline \multicolumn{16}{|l|}{ LIDA JCT. } \\
\hline MEDLIN'S RANCH & 1.6 & 1.3 & 2.9 & 3.1 & & 0.56 & & 7.8 & 7.1 & 8.6 & 2 & 0.00098 & 0.004 & 0.0055 & 0.3 \\
\hline MT. CHARLESTON & & & & & 0.28 & & & & & & & & 0.03 & 0.009 & \\
\hline PAHRUMP & & & & & 0.33 & & & & & & & & 0.033 & 0.0083 & \\
\hline PENOYER FARMS & 1.5 & 1.5 & 2.3 & 2.7 & & 0.43 & 1.1 & 10 & 5.7 & 10 & 1.3 & 0.00085 & & & 0.27 \\
\hline PRISON COMPLEX & & & 1.5 & 2.6 & 0.83 & 0.4 & & & & & 1.3 & 0.00084 & 0.039 & 0.0059 & \\
\hline RACHEL & 1.4 & 1.4 & 2.2 & & & 0.46 & 1 & 8.3 & 5.4 & 9.5 & 1.5 & 0.00035 & & & 0.26 \\
\hline SARCOBATUS FLATS & 1.1 & 2.8 & & 5.3 & & & & 14 & 8.8 & 13 & & & & & 0.5 \\
\hline \multicolumn{16}{|l|}{ SCOTTY'S JCT. } \\
\hline \multicolumn{16}{|l|}{ SCOTTY'S CASTLE } \\
\hline SPRINGDALE & 4.9 & 4.8 & 5.7 & 8.3 & 0.19 & 1.3 & 2.3 & 18 & 12 & 17 & 3.6 & 0.0017 & 0.039 & 0.0064 & 0.5 \\
\hline STATELINE & & & & & 0.24 & 1.2 & & & & & 3.5 & & 0.035 & 0.011 & \\
\hline \multicolumn{16}{|l|}{$\begin{array}{l}\text { STONE CABIN } \\
\text { RANCH }\end{array}$} \\
\hline TOLICHA PEAK & 1.7 & 1.6 & 2.1 & 6.4 & & 0.5 & 0.97 & 17 & & 16 & & 0.00095 & & 0.0058 & 0.47 \\
\hline \multicolumn{16}{|l|}{ TONOPAH } \\
\hline \multicolumn{16}{|l|}{ TWIN SPRINGS RN } \\
\hline U.S. ECOLOGY & 4.2 & 2.8 & 5.5 & 6.6 & 0.26 & 1.4 & 2.2 & 13 & 5.1 & 13 & 3.8 & 0.002 & 0.045 & 0.014 & 0.49 \\
\hline
\end{tabular}


Table 5.0 (Calculated EDEs [ $\mu \mathrm{rem} / \mathrm{yr}$ ], cont.)

\begin{tabular}{|c|c|c|c|c|c|c|c|c|c|c|c|c|c|}
\hline \multirow{3}{*}{ Location } & \multicolumn{13}{|c|}{ EDE ( $\mu \mathrm{rem} / \mathrm{yr})$ due to emissions from: } \\
\hline & Area 12 & Area 13 & Area 15 & Area 16 & Area 17 & Area 18 & Area 19 & Area 20 & Area 30 & $\begin{array}{c}\text { Area } 52 \\
\text { TTR }\end{array}$ & $\begin{array}{c}\text { Area } 12 \\
\text { E Tunnel }\end{array}$ & $\begin{array}{c}\text { Area } 20 \\
\text { Well 20-5\#3 }\end{array}$ & $\begin{array}{l}\text { Area } 20 \\
\text { Schooner }\end{array}$ \\
\hline & \multicolumn{10}{|c|}{${ }^{239+240} \mathrm{Pu}$ and ${ }^{241} \mathrm{Am}$} & \multicolumn{3}{|c|}{ (Tritium) } \\
\hline ALAMO & & 2.1 & 1.3 & & & & & & & & & & \\
\hline AMARGOSA VALLEY & 0.83 & & 1.4 & 0.9 & 2.8 & 10 & & & 2.3 & & 0.031 & 0.00004 & 0.22 \\
\hline ASH MEADOWS & & & & 0.42 & & & & & 1.2 & & & & \\
\hline BEATTY & 1 & & 0.94 & 1 & 3.9 & 24 & 18 & 9 & 4.7 & & 0.03 & 0.000055 & 0.83 \\
\hline CACTUS SPRINGS & & & 16 & 0.18 & 0.73 & & & & & & & & \\
\hline CLARK STATION & & & & & & & & & & 5.6 & & & \\
\hline \multicolumn{14}{|l|}{ CORN CREEK STA. } \\
\hline CRYSTAL & 2.8 & & 5.9 & 0.67 & 2 & 4.9 & & & 1 & & 0.049 & & \\
\hline DEATH VALLEY JCT. & & & & & & & & & 1 & & & & \\
\hline \multicolumn{14}{|l|}{ FURNACE CREEK } \\
\hline GOLDFIELD & & & 16 & 0.18 & 0.67 & & & & 0.41 & & & & \\
\hline HIKO & & & & & & & & & & 6.2 & & & 1.1 \\
\hline INDIAN SPRINGS & & 1.2 & & & & & & & & & & & \\
\hline LATHROP WELLS & 1 & & 1.9 & 1.4 & 4.3 & 14 & 11 & 4.4 & 3 & & 0.033 & 0.000043 & 0.66 \\
\hline LIDA JCT. & & & & & & & & 3 & & 6.2 & & 0.000056 & 1.1 \\
\hline MEDLIN'S RANCH & 1.4 & 3.9 & 2.9 & 0.22 & 0.83 & 2.6 & 3.9 & & & & 0.034 & & \\
\hline \multicolumn{14}{|l|}{ MT. CHARLESTON } \\
\hline \multicolumn{14}{|l|}{ PAHRUMP } \\
\hline PENOYER FARMS & 2.3 & 11 & 2.7 & 0.21 & 1.2 & 4.8 & 9.7 & 1.7 & & 3.1 & 0.033 & 0.000036 & 0.6 \\
\hline PRISON COMPLEX & & & & 0.14 & & & & & & & & & \\
\hline RACHEL & 1.2 & 4.6 & 2.6 & 0.2 & 1.1 & 4.4 & 7.5 & 1.5 & & 2.6 & 0.033 & 0.000035 & 0.58 \\
\hline SARCOBATUS FLATS & 0.63 & & & 0.26 & 2.6 & 8.3 & 11 & 20 & 1.2 & 4.1 & 0.046 & 0.000078 & 1.5 \\
\hline SCOTTY'S JCT. & 1.1 & & & & & 4.3 & 6.8 & 7.2 & 0.61 & 5 & 0.041 & 0.000063 & 1.2 \\
\hline SCOTTY'S CASTLE & & & & & & & & 6.6 & & & & & \\
\hline SPRINGDALE & 1.1 & 0.62 & 2.5 & 0.98 & 4.9 & 32 & 30 & 15 & 2.6 & 2.7 & 0.03 & 0.000035 & 1.1 \\
\hline STATELINE & & & & 0.56 & & & & & 1.2 & & & & \\
\hline STONE CABIN RANCH & & & & & & & & & & 4.4 & & & \\
\hline TOLICHA PEAK & 3 & 1.4 & 3 & 0.3 & 1.7 & 12 & 18 & 24 & 2.7 & 6.3 & 0.055 & 0.00012 & 2.5 \\
\hline TONOPAH & & & & & & & & & & 3.7 & & & \\
\hline TWIN SPRINGS RN & & & & & & & & & & 5.6 & & & \\
\hline U.S. ECOLOGY & 0.96 & & 0.96 & 1.1 & 3.1 & 22 & 14 & 6.5 & 4.4 & & 0.031 & 0.00005 & 0.75 \\
\hline
\end{tabular}


Table 5.0 (Calculated EDEs [ $\mu \mathrm{rem} / \mathrm{yr}$, cont.)

\begin{tabular}{|c|c|c|c|c|}
\hline \multirow[b]{2}{*}{ Location } & \multicolumn{4}{|c|}{ Summary } \\
\hline & & $\begin{array}{l}\text { EDE Sum } \\
(\mu r e m / y r)\end{array}$ & Population & $\begin{array}{c}\text { Collective } \\
\text { EDE } \\
\text { (person-mrem) }\end{array}$ \\
\hline ALAMO & & 7.5 & 500 & 3.755 \\
\hline AMARGOSA VALLEY & & 83.3 & 1,129 & 94.024 \\
\hline ASH MEADOWS & & 15.3 & 24 & 0.366 \\
\hline BEATTY & & 130.4 & 1482 & 193.320 \\
\hline CACTUS SPRINGS & & 52.2 & 10 & 0.522 \\
\hline CLARK STATION & & 5.6 & 0 & 0.000 \\
\hline CORN CREEK STA. & & 1.3 & 4 & 0.005 \\
\hline CRYSTAL & & 76.7 & 77 & 5.904 \\
\hline DEATH VALLEY JCT. & & 1.3 & 7 & 0.009 \\
\hline FURNACE CREEK & & 0.0 & 50 & 0.000 \\
\hline GOLDFIELD & & 7.3 & 574 & 4.190 \\
\hline HIKO & & 1.2 & 103 & 0.124 \\
\hline INDIAN SPRINGS & & 50.7 & 1387 & 70.299 \\
\hline LATHROP WELLS & & 134.4 & 30 & 4.032 \\
\hline LIDA JCT. & & 10.3 & 8 & 0.082 \\
\hline MEDLIN'S RANCH & & 51.1 & 2 & 0.102 \\
\hline MT. CHARLESTON & & 0.3 & 917 & 0.293 \\
\hline PAHRUMP & & 0.4 & 25,450 & 9.450 \\
\hline PENOYER FARMS & & 74.1 & 16 & 1.186 \\
\hline PRISON COMPLEX & & 6.8 & 3199 & 21.804 \\
\hline RACHEL & & 57.7 & 105 & 6.062 \\
\hline SARCOBATUS FLATS & & 95.1 & 16 & 1.522 \\
\hline SCOTTY'S JCT. & & 26.3 & 10 & 0.263 \\
\hline SCOTTY'S CASTLE & & 6.6 & 15 & 0.099 \\
\hline SPRINGDALE & & 172.2 & 20 & 3.443 \\
\hline STATELINE & & 6.7 & 67 & 0.452 \\
\hline STONE CABIN RANCH & & 4.4 & 6 & 0.026 \\
\hline TOLICHA PEAK & & 121.7 & 10 & 1.217 \\
\hline TONOPAH & & 3.7 & 3,134 & 11.596 \\
\hline TWIN SPRINGS RN & & 5.6 & 6 & 0.034 \\
\hline U.S. ECOLOGY & & 112.2 & 45 & 5.050 \\
\hline Total & & & 38403 & 439.231 \\
\hline \multirow{3}{*}{$\begin{array}{l}\text { Total Population: } 38,403 \\
\text { EDE to MEl: } 0.17 \text { mrem } \\
\text { MEI Location: Springdale, NV } \\
\text { Total Person-rem: } 0.44\end{array}$} & \multicolumn{4}{|c|}{$\begin{array}{c}\text { Maximum Individual Dose Calculated from } \\
\text { Following Sources - mrem }\end{array}$} \\
\hline & Tritium & Lab. Sources & ${ }^{239+240} \mathrm{Pu}$ and ${ }^{241} \mathrm{Am}$ & \\
\hline & 0.0017 & 0.0064 & & .17 \\
\hline
\end{tabular}


Table 6.0 Measured Radionuclide Concentrations at Compliance Air Sampling Locations

\begin{tabular}{|c|c|c|c|c|c|}
\hline $\begin{array}{l}\text { Radio- } \\
\text { nuclide }\end{array}$ & Area & Location & $\begin{array}{c}\text { Average } \\
\text { Concentration } \\
(\mathrm{pCi} / \mathrm{m} 3)\end{array}$ & $\begin{array}{c}\text { Percent of } \\
\text { Samples with } \\
\text { Concentrations > } \\
\text { MDC }\end{array}$ & $\begin{array}{c}\text { Concentration } \\
\text { as Percent of } \\
\text { Compliance } \\
\text { Level } \\
\end{array}$ \\
\hline \multirow{6}{*}{${ }^{3} \mathrm{H}$} & 6 & Yucca & $1.11 \times 10^{0}$ & 55 & 0.074 \\
\hline & 10 & Gate 700 South & $5.97 \times 10^{-1}$ & 46 & 0.040 \\
\hline & 16 & Substation 3545 & $6.22 \times 10^{-1}$ & 15 & 0.041 \\
\hline & 20 & Schooner & $4.00 \times 10^{2}$ & 100 & 26.667 \\
\hline & 23 & Mercury & $1.02 \times 10^{-1}$ & 0 & 0.007 \\
\hline & 25 & Guard Station 510 & $5.79 \times 10^{-1}$ & 19 & 0.040 \\
\hline \multirow{6}{*}{${ }^{241} \mathrm{Am}$} & 6 & Yucca & $1.79 \times 10^{-5}$ & 79 & 0.942 \\
\hline & 10 & Gate 700 South & $1.24 \times 10^{-5}$ & 100 & 0.653 \\
\hline & 16 & Substation 3545 & $9.78 \times 10^{-6}$ & 83 & 0.515 \\
\hline & 20 & Schooner & $1.03 \times 10^{-5}$ & 67 & 0.542 \\
\hline & 23 & Mercury & $7.41 \times 10^{-6}$ & 33 & 0.390 \\
\hline & 25 & Guard Station 510 & $5.74 \times 10^{-6}$ & 83 & 0.302 \\
\hline \multirow{6}{*}{${ }^{238} \mathrm{Pu}$} & 6 & Yucca & $1.29 \times 10^{-6}$ & 8 & 0.061 \\
\hline & 10 & Gate 700 South & $3.13 \times 10^{-6}$ & 0 & 0.149 \\
\hline & 16 & Substation 3545 & $6.03 \times 10^{-7}$ & 0 & 0.029 \\
\hline & 20 & Schooner & $1.27 \times 10^{-6}$ & 0 & 0.060 \\
\hline & 23 & Mercury & $3.91 \times 10^{-7}$ & 0 & 0.019 \\
\hline & 25 & Guard Station 510 & $1.16 \times 10^{-6}$ & 0 & 0.055 \\
\hline \multirow{6}{*}{${ }^{239+240} \mathrm{Pu}$} & 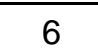 & Yucca & $1.58 \times 10^{-5}$ & 29 & 0.790 \\
\hline & 10 & Gate 700 South & $5.23 \times 10^{-6}$ & 33 & 0.262 \\
\hline & 16 & Substation 3545 & $2.11 \times 10^{-6}$ & 0 & 0.106 \\
\hline & 20 & Schooner & $3.71 \times 10^{-6}$ & 17 & 0.186 \\
\hline & 23 & Mercury & $-1.12 \times 10^{-6}$ & 0 & -0.056 \\
\hline & 25 & Guard Station 510 & $1.89 \times 10^{-6}$ & 0 & 0.095 \\
\hline
\end{tabular}

Table 7.0 Comparison of CAP88-PC Concentrations with Measured Concentrations at Compliance Stations

\begin{tabular}{|c|c|c|c|}
\hline \multirow{2}{*}{$\begin{array}{c}\text { Compliance Air } \\
\text { Sampling Locations }\end{array}$} & \multicolumn{3}{|c|}{ CAP88-PC Conc./Measured Conc. } \\
\hline & HTO & ${ }^{241} \mathrm{Am}$ & ${ }^{239+240} \mathrm{Pu}$ \\
\hline $\begin{array}{l}\text { YUCCA } \\
\text { GATE 700S } \\
3545 \text { SUBSTATION } \\
\text { SCHOONER } \\
\text { MERCURY } \\
\text { GUARD STATION } 510\end{array}$ & $\begin{array}{l}0.313 \\
2.325 \\
0.587 \\
0.975 \\
0.975 \\
0.259\end{array}$ & $\begin{array}{l}1.29 \\
3.66 \\
3.23 \\
5.44 \\
0.70 \\
1.08\end{array}$ & $\begin{array}{c}10.5 \\
59.9 \\
101.5 \\
33.5 \\
-34.1^{(a)} \\
21.1\end{array}$ \\
\hline
\end{tabular}

(a) Negative result due to measured concentration average below zero $\mathrm{pCi} / \mathrm{m}^{3}$. 


\section{CERTIFICATION}

I certify under penalty of law that I have personally examined and am familiar with the information submitted herein and based on my inquiry of those individuals immediately responsible for obtaining the information, I believe that the submitted information is true, accurate and complete. I am aware that there are significant penalties for submitting false information including the possibility of fine and imprisonment. See 18 U.S.C. 1001.

for Name: Kathleen A. Carlson, Manager, NNSAVNV

Signature: Stwen d. Lawrence * Date: 6-26-02

* Copy of Designation of Authority as Acting manager le Her attached. 


\section{Deำ \\ Nevada Operations Office \\ P. O. $80 \times 98518$ \\ Las Vegas, NV $89193-8518$}

\section{JWN 242002}

Steven J. Lawrence, Acting Deputy Assistant Manager for Technical Services, NNSA/NV,

Las Vegas, NV

\section{DESIGNATION OF AUTHORITY AS ACTING MANAGER}

During my, and Kenneth W. Powers', absence from the office on June 26-27, 2002, or until our return, you are hereby designated Acting Manager. You are authorized to exercise full authority for this position in accordance with the NV M 111.XA, Functions, Responsibilities, and Authorities Manual approved September 7, 2000.

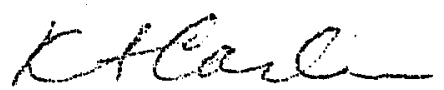

Kathleen A. Carlson

Manager

OMGR:KAC

AOM-05-01

cc:

DMGR

AMNS

AAMTS

OCC

AMEM

OPA

OQLD

USAF/DOE Liaison

Office 


\section{SECTION IV \\ ADDITIONAL INFORMATION}

\section{NEW CONSTRUCTION/MODIFICATION ACTIVITIES AT THE NTS}

During CY 2001, no new construction or modification to existing facilities involving radioactive materials was initiated.

\section{UNPLANNED RELEASES DURING CALENDAR YEAR (CY) 2001}

No unplanned release occurred on the NTS during CY 2001. There was a detectable non-NTS release, at the Atlas Facility, located in North Las Vegas, that was a continuance of a 1995 incident (see Appendix A for a description).

\section{SOURCES OF DIFFUSE OR FUGITIVE EMISSIONS}

This year these sources included the following:

- Evaporation from containment ponds that receive liquid effluents from E Tunnel in Area 12.

- Evaporation of water discharged from Well U-3cn PS\#2 and Well ER-20-5 \#3 into lined containment ponds.

- Re-suspension of ${ }^{241} \mathrm{Am}$ and ${ }^{239+240} \mathrm{Pu}$ from soil deposits on the NTS areas listed in Table 1.0.

- Transpiration of tritium from the SEDAN and SCHOONER craters.

- Low-level waste packages buried at the RWMS-5.

The EDE to the MEI was principally due to the diffuse sources. The EDE from point sources was negligible. The methods used to determine the emissions from these diffuse sources are described in the Appendices A-E. 
This page intentionally left blank 
FIGURES 
This page intentionally left blank 


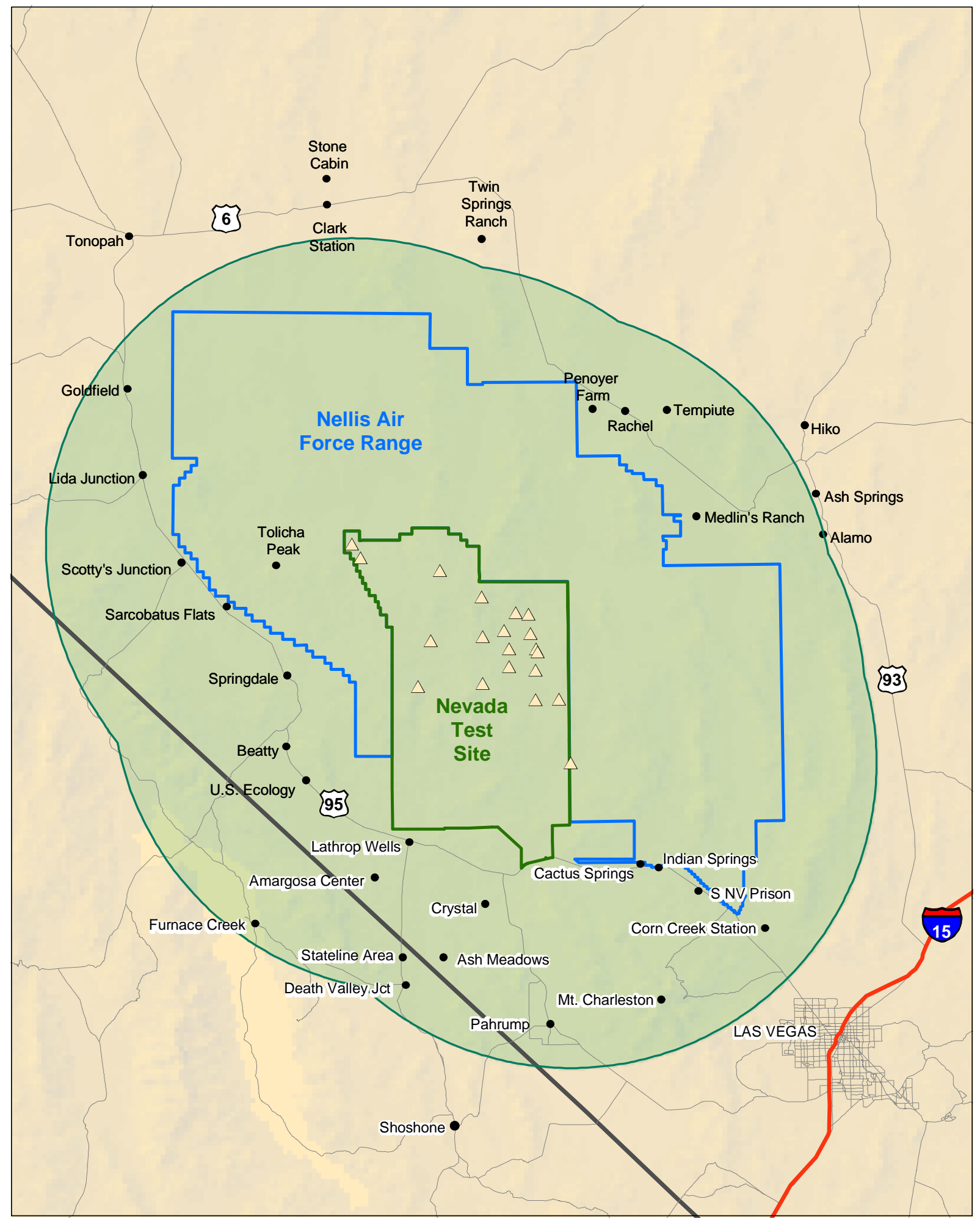

$\triangle$ Potential Emission Source $80 \mathrm{Km}$ Boundary

$\sim$ Nevada Test Site

Primary Road

- Populated Areas

Nellis Air Force Range $\frown$ Interstate

State Boundary

\begin{tabular}{rrr}
0 & $10 \quad 20$ & 40 \\
\hline
\end{tabular}

$\begin{array}{lll}0 & 12.5 & 25\end{array}$

50

Kilometers

Figure 1.0 Map of the Nevada Test Site and Surrounding Areas 


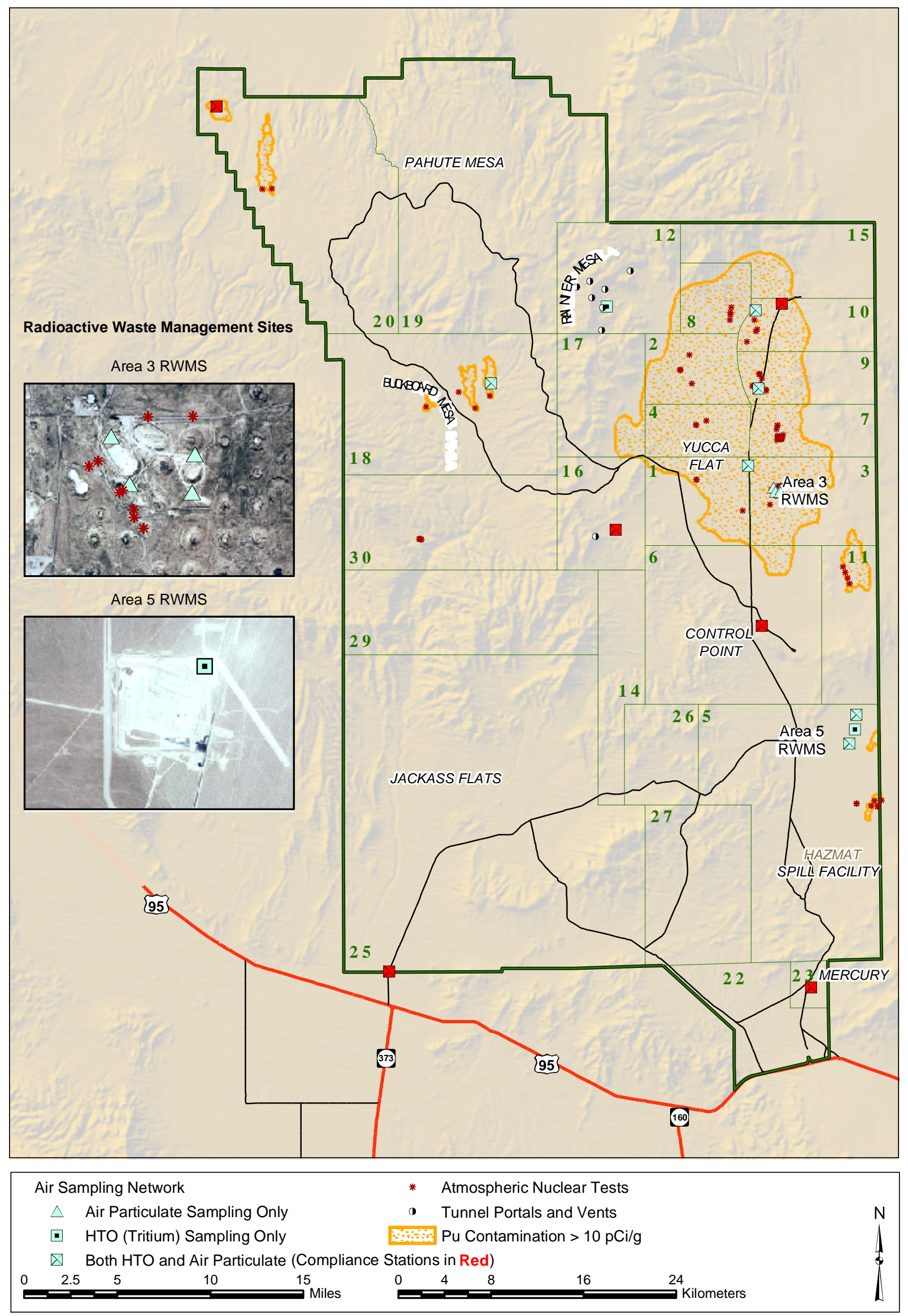

Figure 2.0 Air Sampling Network on the Nevada Test Site - 2001 


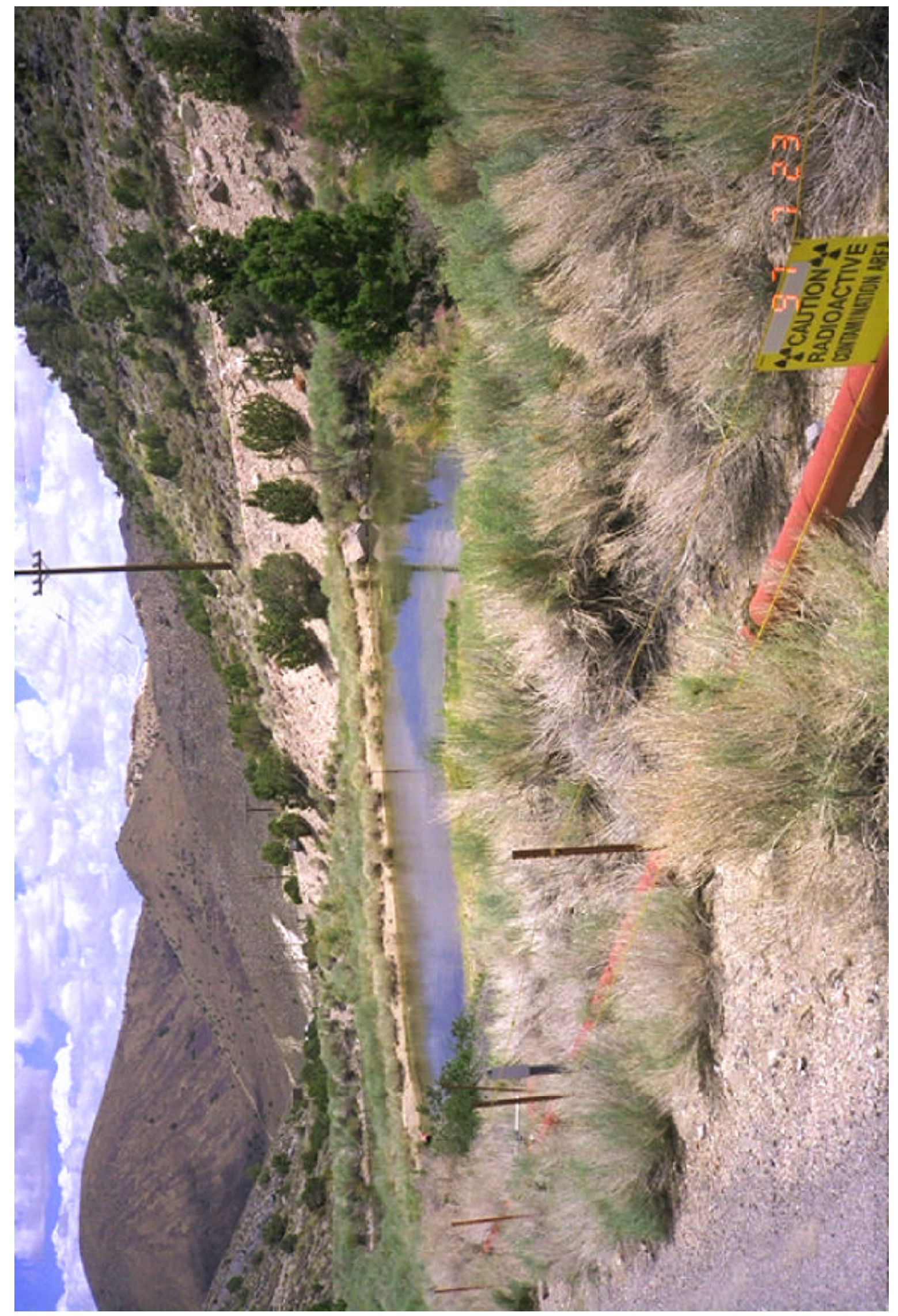

Figure 3.0 Photograph of E Tunnel Containment Ponds (07-23-97) 

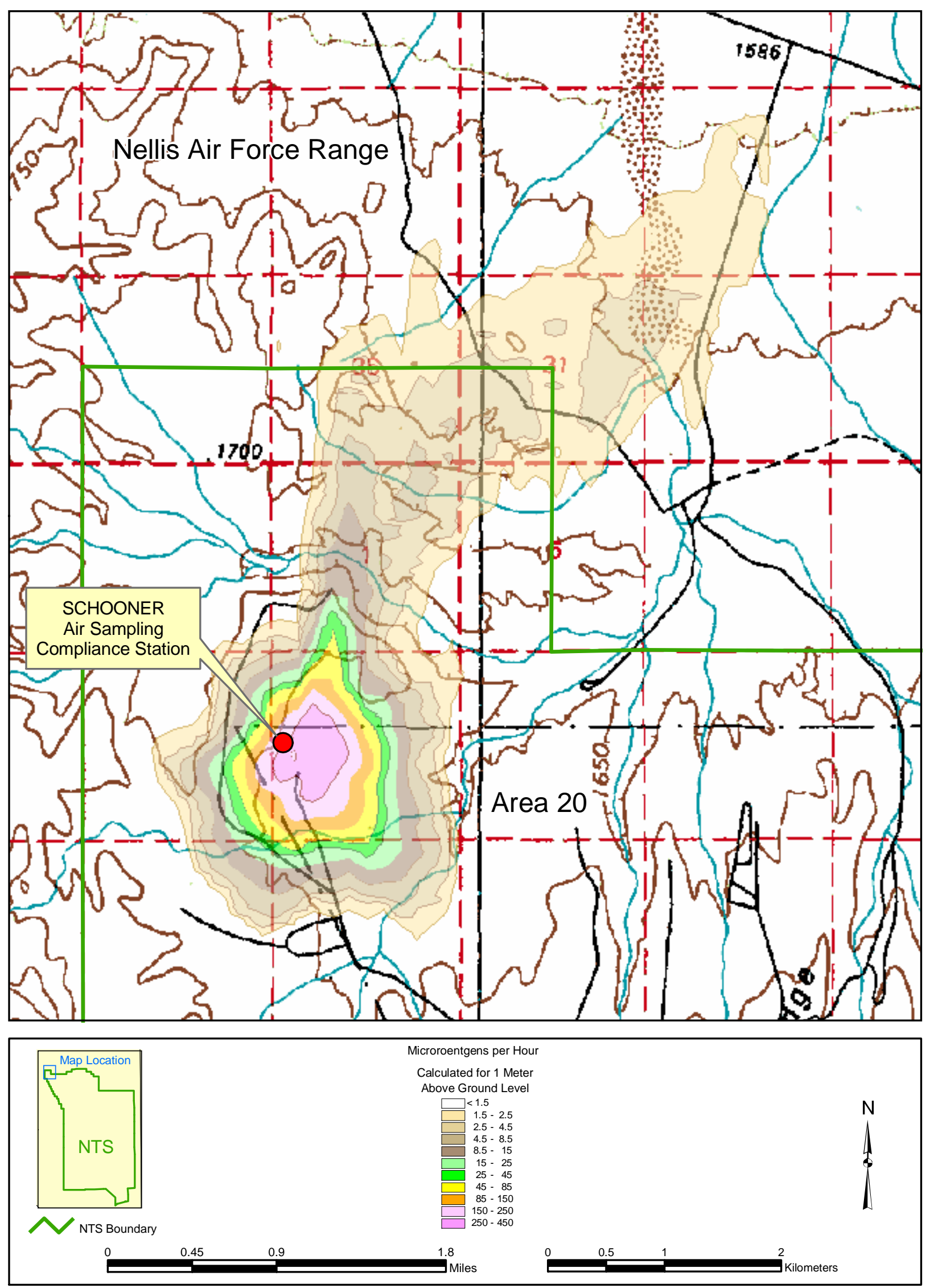

Figure 4.0 SCHOONER Air Sampling Compliance Station 
APPENDICES 
This page intentionally left blank 


\section{APPENDIX A}

\section{PUBLIC DOSE CALCULATIONS FOR THE ATLAS TRITIUM INCIDENT}

\section{ENVIRONMENTAL SURVEILLANCE}

As reported in the 1995 NESHAPs report (DOE 1996b), a container of tritium foils was opened in the Atlas Facility at the North Las Vegas Operations area that emitted about $1 \mathrm{Ci}$ of ${ }^{3} \mathrm{H}$ into a basement area used as a fixed radiation source range. Environmental surveillance began with notification on Friday, July 14, 1995, that the tritium leak had occurred. Environmental HTO samplers were installed at three locations outside the facility. Later, an HTO sampler was installed in the basement so that progress on cleanup of the spill could be monitored. After cleanup began, the environmental samplers were removed, but the basement air sampler continued operation through January 5,1998 , at which time, only two-week samples were collected each quarter. The 1996, 1997, and 1998 results and offsite EDEs were reported in the respective annual NESHAPs reports.

In 2001, two tritiated atmospheric moisture samples were collected in the Building A-1 basement. The results are as follows:

Location

Building A-1, Rm. 4862

Average

\section{Collection Period}

$12 / 23 / 2000$ to $01 / 10 / 2001$

$01 / 10 / 2001$ to $01 / 30 / 2001$
Tritium Conc. $\left(\mathrm{pCi} / \mathrm{m}^{3}\right)$

18,500

$\frac{21,500}{20,000}$

From the average tritium concentration for room 4862, the EDE for a hypothetical MEI (100 m northwest of the exhaust vent as determined from the 1995 NESHAPS evaluation) was calculated by the following method:

- The volume rate of air discharged to the atmosphere from the Building A-1 basement (673 cfm) during 2001 was calculated from information obtained from an industrial hygiene ventilation survey conducted on October 22, 1998. According to industrial hygiene personnel, no changes in the ventilation system have been made since then.

- The total tritium discharged was calculated by multiplying the average tritium concentration above by the air volume discharge rate and the number of minutes per year $\left(20,000 \mathrm{pCi} / \mathrm{m}^{3} \times 673 \mathrm{ft}^{3} / \mathrm{min} \times 0.02832 \mathrm{~m}^{3} / \mathrm{ft}^{3} \times 5.26 \times 10^{5} \mathrm{~min} / \mathrm{yr} \times 10^{-9} \mathrm{mCi} / \mathrm{pCi}\right)$ to get $200 \mathrm{mCi} / \mathrm{yr}$.

- The EDE for the MEI at the northern facility fence was calculated by multiplying the estimated total annual discharge of tritium by the CAP88-PC dose factor for that location. The resulting EDE is $(200 \mathrm{mCi} / \mathrm{yr})\left(4.8 \times 10^{-6} \mathrm{mrem} / \mathrm{mCi} / \mathrm{yr}\right)(1000 \mathrm{ì} \mathrm{rem} / \mathrm{mrem})$ or 0.96 ì rem/yr.

For comparison, the NESHAPs specifies a limit of 10 mrem to the MEI, which is a factor of 10,400 greater than the calculated EDE. 
This page intentionally left blank 


\section{APPENDIX B}

\section{EMISSIONS FROM CONTAINMENT PONDS}

\section{E TUNNEL PONDS}

Effluent water from the Area $12 \mathrm{E}$ Tunnel and any containment ponds receiving that water was sampled quarterly. During 2001, these water samples were analyzed for tritium (as HTO). The flow rate of water discharged from the tunnels was measured monthly. The total amount of radioactive liquid effluent from the tunnels was calculated from the concentration of tritium in the water and the total volume of water discharged during the year, based on the monthly flow-rate measurements.

In order to calculate doses using CAP88-PC, an airborne source term must be known. By assuming that the total amount of tritium (as HTO) measured in the liquid effluent during the year evaporates and becomes airborne, a conservative estimate of the airborne source term is obtained. It is unlikely that this is a true source term for the containment pond, but it is an upper limit of the effluents which could be released. Despite efforts to seal it, $E$ Tunnel is still a source of HTO to the tunnel ponds. This year it was estimated that 14 curies of HTO were discharged into the ponds.

From the estimated tritium discharged from $\mathrm{E}$ Tunnel, the EDE to the MEI was calculated with CAP88-PC software. The MEI for the Area 12 emission was found to reside at Tolicha Peak, Nevada, an Air Force radar and communications facility $53 \mathrm{~km}$ west northwest of the tunnel ponds, where the individual would have received an EDE of $5.5 \times 10^{-5} \mathrm{mrem}\left(5.5 \times 10^{-7} \mathrm{mSv}\right)$.

\section{WELL DISCHARGES}

In CY 2001, water containing tritium was pumped from two wells into containment ponds from which the water was assumed to completely evaporate during the year. The estimated tritium emissions for the year based upon the total water discharged and the measured tritium concentrations in the water were $0.94 \mathrm{Ci}$ from Well U-3cn PS\#2 (Area 3) and 0.016 Ci from Well ER-20-5 \#3 (Area 20). From CAP88-PC software and these estimated emissions, the EDEs to the MEls for these emissions were calculated as follows for the wells listed below:

- Well U-3cn PS\#2 - $2.0 \times 10^{-3} / \mathrm{yr}$ at Lathrop Wells or U. S. Ecology, which are $57 \mathrm{~km}$ southwest and $67 \mathrm{~km}$ west southwest, respectively

- Well ER-20-5 \#3 - $1.2 \times 10^{-4} \mathrm{i} \mathrm{rem} / \mathrm{yr}$ at Tolicha Peak, which is $28 \mathrm{~km}$ west northwest

\section{EVAPORATION OF WATER - EPA'S RECOMMENDATION}

A calculation was performed in the 1995 NESHAPs report (DOE 1996b) to estimate tritium emission from the E Tunnel pond during 1994, using the 1992 EPA methods for estimating diffuse emissions. It was concluded that the EPA's methods seriously underestimated the effluent source term; therefore, the calculation was not repeated. For reference, the equation used for that calculation is repeated below. 


$$
E=\frac{20.73 x P_{s} x A^{0.9} x U^{0.8}}{T^{1.47}}
$$

where $\quad E=$ evaporation rate, $g / s$

$A=$ surface area of pond, $\mathrm{m}^{2}$

$P_{S}=$ equilibrium water vapor pressure at

$\mathrm{U}=$ wind speed, $\mathrm{m} / \mathrm{s}$ ambient temperature, $\mathrm{mm} \mathrm{Hg}$

$\mathrm{T}={ }^{\mathrm{O}} \mathrm{K}={ }^{\circ} \mathrm{C}+273.2$

Use of the equation resulted in a source term of $2.4 \mathrm{Ci}$ for 1995 when total evaporation would yield a more conservative source term estimate of $260 \mathrm{Ci}$. 


\section{APPENDIX C}

\section{POTENTIAL RADIONUCLIDE EMISSIONS FROM RADIOANALYTICAL LABORATORIES}

\section{Building 650 Source Storage Room}

Following the closure of the Analytical Services Laboratory in Building 650, all the standards, check sources, and tracer solutions were stored in a basement room until all items can be properly disposed of. The activity contained in these sources was orders of magnitude above that contained in samples (based on data collected in previous years).

From an inventory of these materials, only three of them are volatile and could become a source of air emissions. These are ${ }^{3} \mathrm{H}$ (as HTO), ${ }^{129} \mathrm{I}$, and ${ }^{85} \mathrm{Kr}$ and are in the following quantities:

$\begin{array}{ll}{ }^{3} \mathrm{H} & 3.0 \times 10^{-4} \mathrm{Ci} \\ { }^{85} \mathrm{Kr} & 8.7 \times 10^{-2} \mathrm{Ci} \\ { }^{129} \mathrm{I} & 5.4 \times 10^{-7} \mathrm{Ci}\end{array}$

All of the standards and solutions were less than the possession limits set forth in Title 40 CFR 61 Appendix E. Since no portion of these sources were released or consumed during the year, no emission was estimated.

\section{Los Alamos National Laboratory}

In previous years, this laboratory maintained standards of radioactivity containing ${ }^{133} \mathrm{Xe},{ }^{131} \mathrm{I}$, and ${ }^{3} \mathrm{H}$. Due to the test moratorium that began in 1992, the need for standards was reduced and the only standard of significance for airborne emission maintained in 2001 was 46 i Ci of tritium, which is no change from last year. The use of the standards during the year did not result in any release to the atmosphere, so no emission was calculated.

\section{Area 6 CP-50 Laboratory}

The 5.6 Ci of tritium in a pressurized tank previously located at the DAF laboratory was moved to CP-50 Laboratory and consumed while calibrating equipment. The release was used as the source term for a CAP88-PC calculation of the hypothetical EDEs that could have been received by offsite residents within $80 \mathrm{~km}$ of the laboratory. From the calculation, the EDE to the MEI was $0.12 \mu \mathrm{rem} / \mathrm{yr}$ at Amargosa, Nevada, which is $55 \mathrm{~km}$ southwest of the laboratory. 
This page intentionally left blank 


\section{APPENDIX D}

\section{ATMOSPHERIC TRITIUM EMISSIONS FROM DIFFUSE SOURCES BACKGROUND INFORMATION}

Environmental monitoring for tritium in atmospheric moisture was conducted at 10 locations on the NTS until July 2001, when the number of locations was increased to 14 and realigned to conform to a change in strategy for demonstrating compliance with NESHAPs (see Compliance Assessment in Section III). There were four air samplers around the perimeter of RWMS-5 because many curies of ${ }^{3} \mathrm{H}$ are buried at that facility; however, all but one sampler at the northeast corner were terminated and samplers identified as DOD and Sugar Bunker North were added north and south of the compound within the prevailing downwind sectors of the facility. Other air samplers, operated at locations with levels of tritium greater than the MDC, were operated at the E Tunnel pond area, near the SEDAN crater, and near the SCHOONER crater.

\section{SOURCE TERM ESTIMATES}

The method for estimating the tritium emissions as HTO from air sampling data requires a CAP88-PC estimate, of the air concentration at the location of each air sampler. This estimate is from a $1 \mathrm{Ci}$ release from the center of the source for each source location, which was the center of the compound for Area 5 RWMS and the center of the craters for SEDAN and SCHOONER. The total annual emission was estimated by dividing the annual average concentration of HTO measured at each sampling location by the CAP88-PC concentration for a $1 \mathrm{Ci}$ release. The monitoring results from the airborne-tritium sampling stations and estimated emissions are provided in Table D.1. The emission for E Tunnel in this table was not estimated from air sampling data because the estimate from the total water pond influent and measured tritium concentrations as described in Appendix B was more conservative.

These emissions were then used as source terms for CAP88-PC calculations to determine the estimated EDEs for all populated offsite locations within $80 \mathrm{~km}$ of each of the sources of emission (see Table 5.0). 
Table D.1 Airborne Tritium Sampling Results During CY - 2001

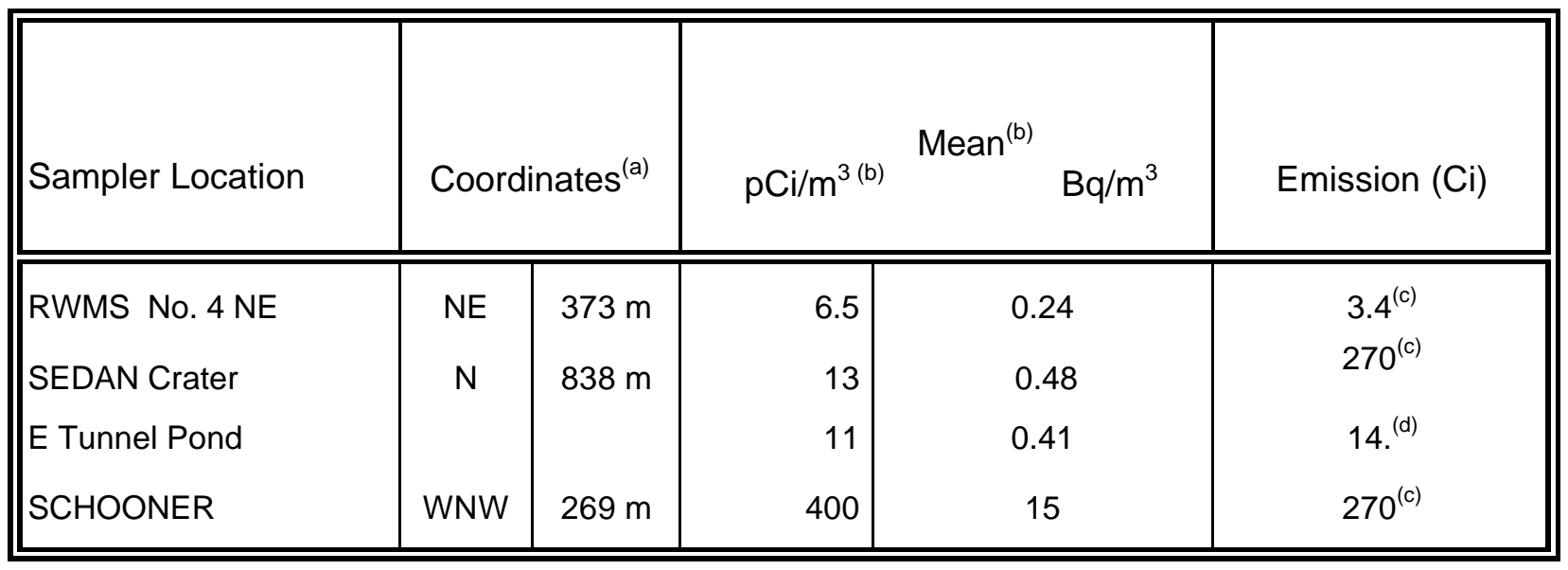

(a) Sampler direction and distance from center of suspected source. Distances for RWMS No. $4 \mathrm{NE}$ and SEDAN Crater changed from those reported last year due to more accurate surveys of sampler locations.

(b) Median MDC is $1.0 \mathrm{pCi} / \mathrm{m}^{3}$.

(c) Estimated number of curies emitted from the source that would give the sampler result.

(d) Estimated from total water discharged and tritium concentration measurements. 


\section{APPENDIX E}

\section{RESUSPENDED AMERICIUM AND PLUTONIUM FROM YUCCA FLAT AND OTHER AREAS}

\section{BACKGROUND INFORMATION}

Areas 1-12 and 15-20 on the NTS, Area 13 on the NAFR, and the CLEAN SLATE sites on the NAFR at the Tonopah Test Range contain diffuse sources of radionuclide effluents. Due to occasional high winds, some contaminated soil becomes airborne. Results from the air samplers, in these areas, indicate that ${ }^{241} \mathrm{Am}$ and ${ }^{239+240} \mathrm{Pu}$ are routinely detected, but only in concentrations slightly above the MDC.

\section{SOURCE TERM FROM RE-SUSPENSION CALCULATIONS}

A conservative estimate of americium and plutonium emissions from diffuse sources is obtained by the use of a re-suspension equation with parameters derived from actual studies at the NTS. In NUREG/CR-3332 (NRC 1983), page 5-30, an equation for calculating a suspension rate (fraction resuspended per second) is given as follows:

$$
S=K \times V_{g}
$$

where: $\mathrm{S}=$ suspension rate $\left(\mathrm{sec}^{-1}\right)$ - fraction of the deposit resuspended/sec

$\mathrm{K}=$ re-suspension factor $\left(\mathrm{m}^{-1}\right)$

$\mathrm{V}_{\mathrm{g}}=$ deposition velocity $(\mathrm{m} / \mathrm{s})$

On page 75 of report DOE/NV--357 (DOE 1992), values of $\mathrm{K}$ are given for the NTS. An average of the values given is $2 \times 10^{-10} / \mathrm{m}$. Deposition velocities in the range of 0.01 to $0.05 \mathrm{~m} / \mathrm{s}$ will be used as conservative estimates. If these values are put into the above equation, the rate of resuspension is between $2 \times 10^{-12}$ and $1 \times 10^{-11} / \mathrm{s}$. To be conservative, the higher re-suspension rate of $1 \times 10^{-11} / \mathrm{s}$ will be used. For Area 3, the source term rate is then calculated from the product of the ${ }^{239+240} \mathrm{Pu}$ deposition $(37 \mathrm{Ci}$ ) from Table 1.0 and re-suspension rate, as follows:

$$
37 \mathrm{Ci} \times 10^{12} \mathrm{pCi} / \mathrm{Ci} \times 1 \times 10^{-11} / \mathrm{s}=370 \mathrm{pCi} / \mathrm{s} \text {. }
$$

Since 1 year $=3,600 \mathrm{~s} / \mathrm{hr} \times 24 \mathrm{hr} /$ day $\times 365$ days $/ \mathrm{yr}=3.15 \times 10^{7} \mathrm{sec} / \mathrm{yr}$, the annual source term becomes:

$$
370 \mathrm{pCi} / \mathrm{s} \times 3.15 \times 10^{7} \mathrm{~s} / \mathrm{yr}=1.17 \times 10^{10} \mathrm{pCi} / \mathrm{yr}(12 \mathrm{mCi} / \mathrm{yr}) .
$$

This method was used for calculating the ${ }^{241} \mathrm{Am}$ and ${ }^{239+240} \mathrm{Pu}$ emissions from all other areas. The results are shown at the end of Table E.1. The EDEs due to re-suspension for each of the areas were then determined from CAP88-PC calculations using the individual area emission rates. The results are listed in Table 5.0.

\section{OTHER ISOTOPES}

The other predominant isotopes that have been found in soil samples in the various areas on the NTS are ${ }^{137} \mathrm{Cs}$ and ${ }^{238} \mathrm{Pu}$. The cesium isotope is neglected because it migrates readily and, in eight to ten years after assessment in the soil, only a fraction will remain in the surface layer. Since the ${ }^{238} \mathrm{Pu}$ concentration in air is usually below the MDC, this isotope has also not been included in evaluations for NESHAP compliance. 
Table E.1 Calculated Emissions from Inventories ${ }^{(a)}$ of Plutonium and Americium in NTS Areas

\begin{tabular}{|c|c|c|c|c|c|c|}
\hline \multicolumn{7}{|c|}{$\mathrm{S}($ Re-suspension in $\mathrm{Ci})=\mathrm{Ci} \times \mathrm{K} \times \mathrm{Vg} \times 1 \mathrm{E}+03 \mathrm{mCi} / \mathrm{Ci} \times 3.15 \mathrm{E}+07 \mathrm{~s} / \mathrm{yr}$} \\
\hline Area & $\begin{array}{l}{ }_{(\mathrm{Ci})}^{241} \mathrm{Am} \\
\text { ( }\end{array}$ & $\begin{array}{c}{ }^{239+240} \mathrm{Pu} \\
(\mathrm{Ci})\end{array}$ & $\underset{\left(m^{-1}\right)}{K}$ & $\begin{array}{c}\mathrm{Vg} \\
(\mathrm{m} / \mathrm{s})\end{array}$ & $\underset{(\mathrm{mCi} / \mathrm{yr})}{\mathrm{S} \text { for }}$ & $\begin{array}{c}\begin{array}{c}\text { S for } \\
{ }_{239+240} \mathrm{Pu} \\
\text { (mCi/yr) }\end{array} \\
\end{array}$ \\
\hline 1 & 4.2 & 24 & 2.E-10 & 5.E-02 & 1.32 & 7.6 \\
\hline 2 & 2.9 & 22 & 2.E-10 & 5.E-02 & 0.91 & 6.9 \\
\hline 3 & 4.6 & 37 & 2.E-10 & 5.E-02 & 1.45 & 11.7 \\
\hline 4 & 6.6 & 40 & 2.E-10 & 5.E-02 & 2.08 & 12.6 \\
\hline 5 & 0.6 & 4.8 & 2.E-10 & 5.E-02 & 0.19 & 1.5 \\
\hline 6 & 1.7 & 8.4 & 2.E-10 & 5.E-02 & 0.54 & 2.6 \\
\hline 7 & 2.2 & 16 & 2.E-10 & 5.E-02 & 0.69 & 5.0 \\
\hline 8 & 17. & 110 & 2.E-10 & 5.E-02 & 5.36 & 34.7 \\
\hline 9 & 4.2 & 89 & 2.E-10 & 5.E-02 & 1.32 & 28.0 \\
\hline 10 & 19. & 110 & 2.E-10 & 5.E-02 & 5.99 & 34.7 \\
\hline 11 & 3.3 & 29 & 2.E-10 & 5.E-02 & 1.04 & 9.1 \\
\hline 12 & 5.7 & 39 & 2.E-10 & 5.E-02 & 1.80 & 12.3 \\
\hline 15 & 8.0 & 63 & 2.E-10 & 5.E-02 & 2.52 & 19.8 \\
\hline 16 & 0.7 & 3.7 & 2.E-10 & 5.E-02 & 0.22 & 1.2 \\
\hline 17 & 2.8 & 18 & 2.E-10 & 5.E-02 & 0.88 & 5.7 \\
\hline 18 & 19. & 100 & 2.E-10 & 5.E-02 & 5.99 & 31.5 \\
\hline 19 & 21. & 140 & 2.E-10 & 5.E-02 & 6.62 & 44.1 \\
\hline 20 & 23. & 41 & 2.E-10 & 5.E-02 & 7.25 & 12.9 \\
\hline 30 & 3.2 & 14 & 2.E-10 & 5.E-02 & 1.01 & 4.4 \\
\hline TOTAL & 140 & 910 & & & 47. & 290 \\
\hline \multicolumn{7}{|l|}{ Offsite } \\
\hline 13 & 2.88 & 46 & 2.E-10 & 5.E-02 & 0.91 & 14.5 \\
\hline CS II & 1.06 & 17 & 2.E-10 & 5.E-02 & 0.33 & 5.4 \\
\hline CS III & 2.31 & 37 & 2.E-10 & 5.E-02 & 0.73 & 11.7 \\
\hline TOTAL & 6.3 & 100 & & & 2.0 & 32 \\
\hline
\end{tabular}

(a) Radioactive inventories from Table 5 in DOE/NV/10845-02, except for Area 13 and Clean Slates where $\mathrm{Pu}-239 / 240$ inventories are from Table 3-13 in DOE/NV-357 (Revision 2) and Am-241 inventories calculated from $1 / 16$ of Pu-239/240 inventories. 


\section{EPA METHOD FOR ESTIMATING DIFFUSE EMISSIONS}

Using the equation in EPA's Methods for Estimating Diffuse Emissions (unpublished), a wind erosion calculation for Area 9 for comparison with the NTS NESHAPs report calculation can be done. To illustrate this calculation, the equation on page 18 of the EPA report is used:

$$
E^{\prime}=k \cdot a \cdot I \cdot K \cdot C \cdot L^{\prime} \cdot V^{\prime} \cdot A \cdot C
$$

where: $\quad E^{\prime}=$ soil particles lost (tons/yr)

$\mathrm{k}=$ particle size factor

$\mathrm{a}=$ total suspended fraction lost to wind erosion

$\mathrm{I}=$ soil erodibility (tons/acre-yr)

$\mathrm{K}=$ surface roughness factor

$C=$ climatic factor $-C=0.345\left(\mathrm{mph}^{3} / \mathrm{PE}^{2}\right)$ where $\mathrm{PE}=0.83$

$L^{\prime}=$ unsheltered field width factor

$\mathrm{V}^{\prime}=$ vegetative cover factor

$A=$ site area $\left(\mathrm{m}^{2}\right)$ - use high density of $75.6 \mathrm{Ci}$ on $7.5 \mathrm{mi}^{2}$

$\mathrm{C}=$ conversion factor tons/acre to $\mathrm{kg} / \mathrm{m}=0.224$

Inputs: $\quad$ Yucca Flat is typical high plain desert with sparse vegetation. Average wind speed is $6.0 \mathrm{knots}=6 \times 0.514 \mathrm{~m} / \mathrm{s}=3.08 \mathrm{~m} / \mathrm{s}=11.1 \mathrm{~km} / \mathrm{hr}(6.9 \mathrm{mph})$.

$k=0.5$ (fraction of resuspended soil that is $\mathrm{PM}_{10}$ )

$\mathrm{a}=0.025$ portion of total erosion that is suspended particulates

$I=28$ (silty clay loam from Table 7-1, desert pavement decreases erodibility)

$\mathrm{K}=1$ (surface roughness - desert is smooth)

$\mathrm{C}=164$ (climatic factor calculated from $\mathrm{C}=0.345(\mathrm{mph})^{3} /(0.83)^{2}$

$L^{\prime}=0.3$ as read from Figure 7-5 (IK $=28 \times 0.6=17, L=500$ from Table 7-3)

$V^{\prime}=0.95$ (read from Figure 7-6 using $V=100$ from Table 7-3 and IKCL'= 790)

$A=7.5 \mathrm{mi}^{2}=1.9 \times 10^{\prime} \mathrm{m}^{2}$ (from DOE 1991).

so

$E^{\prime}=0.5 \times 0.025 \times 28 \times 1 \times 164 \times 0.3 \times 0.95 \times 0.224=3.7 \mathrm{~kg} / \mathrm{m}^{2}-\mathrm{yr}$

Area 9 (from McArthur in DOE 1991):

$89 \mathrm{Ci}$ on $20 \mathrm{mi}^{2}\left(20 \times 2.59 \times 10^{6} \mathrm{~m}^{2} / \mathrm{mi}^{2}\right)$ or $5.2 \times 10^{7} \mathrm{~m}^{2}$

Total Emission $=3.7 \mathrm{~kg} / \mathrm{m}^{2}-\mathrm{yr} \times 5.2 \times 10^{7} \mathrm{~m}^{2}=1.9 \times 10^{8} \mathrm{~kg} / \mathrm{yr}$

Plutonium concentration in dust (assuming all plutonium is in top $5 \mathrm{~cm}$ ):

$5.2 \times 10^{7} \mathrm{~m}^{2} \times 10^{4} \mathrm{~cm}^{2} / \mathrm{m}^{2} \times 5 \mathrm{~cm}$ deep $\times 1.5 \mathrm{~g} / \mathrm{cm}^{3}=3.9 \times 10^{12} \mathrm{~g}$

$89 \mathrm{Ci} \times 10^{12} \mathrm{pCi} / \mathrm{Ci} \div 3.9 \times 10^{12} \mathrm{~g}=23 \mathrm{pCi} / \mathrm{g}$ or $23 \mathrm{nCi} / \mathrm{kg}$

and the source-term becomes:

$$
23 \times 10^{-9} \mathrm{Ci} / \mathrm{kg} \times 1.9 \times 10^{8} \mathrm{~kg} / \mathrm{yr}=4.4 \mathrm{Ci} / \mathrm{yr}
$$

If the total deposit in Area 9 is $89 \mathrm{Ci}$ and if the $\mathrm{E}^{\prime}$ calculation performed above is correct, then $89 \mathrm{Ci} \div 4.4 \mathrm{Ci} / \mathrm{yr}=20.2$ suggests that the deposit would be depleted in little more than 20 years.

The re-suspension equation calculation for Area 9 ( $0.028 \mathrm{Ci} / \mathrm{yr})$ in Table E-1 would require about 3,200 years to deplete the deposit. 
This page intentionally left blank

\section{E-4}




\section{APPENDIX F}

\section{IDENTIFICATION AND JUSTIFICATION FOR THE DEVELOPMENT OF METEOROLOGICAL DATA USED AS INPUT TO CAP88-PC}

\section{INTRODUCTION}

The NTS is located in southern Nevada, approximately $105 \mathrm{~km}$ (65 mi) northwest of Las Vegas, Nevada and encompasses an approximate rectangular area of approximately $1,375 \mathrm{mi}^{2}$ (see Figure F.1). Topography is complex with generally north-south oriented ridges and valleys typical of Nevada. Terrain elevations range from almost 2,700 ft in the extreme southwest corner of the NTS (Area 25) to almost 7,700 ft on Rainier Mesa in the northern part of the NTS (Area 12).

In general, terrain slopes gently into broad valleys. In the few areas where steep canyons or cliffs exist, adequate wind and temperature data have been collected and analyzed to provide thorough documentation of the existence of typical up-slope and down-slope wind regimes as a function of time of day.

Meteorological support, observations, and climatological services for the NTS are provided to the NNSA/NV by the ARL/SORD. The ARL/SORD is a National Oceanic and Atmospheric Administration (NOAA) office and supports NNSA/NV programs under the authority of an Interagency Agreement between NOAA and NNSA/NV.

An arid climate exists over the NTS. Annual precipitation ranges from $4.5 \mathrm{in} / \mathrm{yr}$ at Station No. 25, to $6.8 \mathrm{in} / \mathrm{yr}$ at Yucca Flat (Station No. 6), to $7.6 \mathrm{in} / \mathrm{yr}$ at Desert Rock, to $12.8 \mathrm{in} / \mathrm{yr}$ on Rainier Mesa (Station No. 12).

\section{METEOROLOGICAL OBSERVATIONS}

The ARL/SORD manages, operates, and maintains a meteorological monitoring program that is designed and used to support the NNSA/NV authorized activities on the NTS. This vital program consists of many meteorological monitoring systems that have been brought together under the Meteorological Integrated Data Network (MIDNET). This network has been operated on the NTS for over 30 years, has undergone several modernizations and upgrades, and serves as a solid basis for deriving climatological information.

MIDNET consists of communications systems, local area networks, upper air sounding stations, and surface based instrumentation used to measure wind direction and speed, temperature, relative humidity, pressure, and precipitation. Routine and special surface observations are collected by trained ARL/SORD personnel $16 \mathrm{hr} /$ day, 365 days/yr at the DRA (elevation 3,304 ft) located three miles southwest of Mercury, Nevada (Station No. 23). Upper-air observations (radiosondes) are taken twice daily from DRA. DRA has been in operation since May 1978. DRA was built to replace a similar observatory that was located at the Yucca Flat Meteorological Observatory (UCC, elevation 3,924 ft, Station No. 6) from January 1962 through mid May 1978. Consequently, surface and upper-air observations are also available from UCC for 1962-1978. 


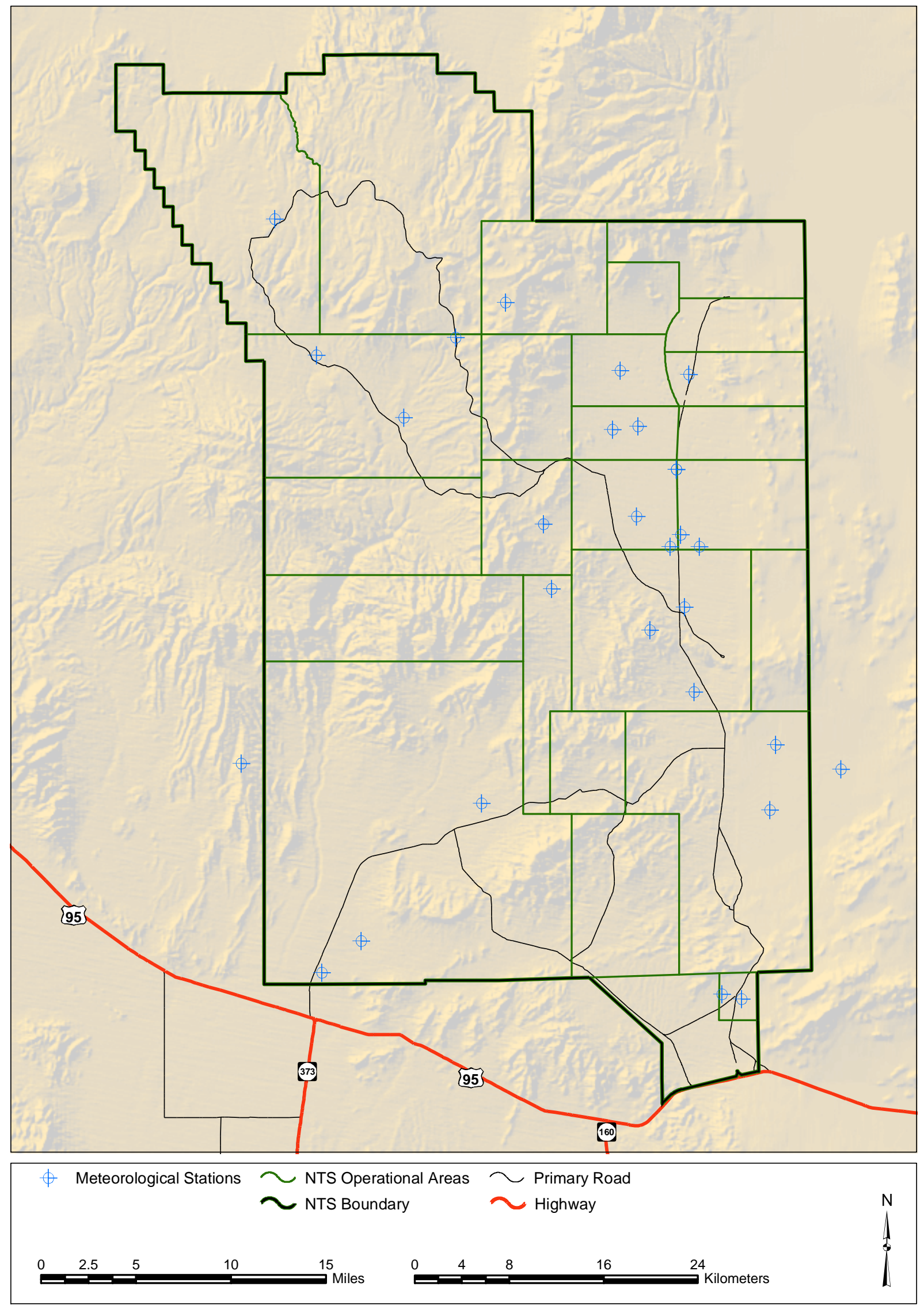

Figure F.1 Locations of Meteorological Data Acquisition System (MEDA) Stations on the NTS - 2001 F-2 
A key component of the MIDNET system is the MEDA. The MEDA consists of an enclosed trailer, a portable 10-m tower, (an electric generator where needed), a microprocessor, and a microwave radio transmitter. Wind speed and direction sensors are located on booms oriented into the prevailing wind direction and at a minimum distance of two tower widths from the tower. Wind sensors are located $10 \mathrm{~m}$ above the ground.

Wind and temperature data have been collected on the NTS for more than 40 years. These and other meteorological data have been compiled into a comprehensive climatological database for the NTS. The MEDA data are especially useful in assessing boundary layer flow regimes on the NTS. MEDA station distribution and density (see Figure F.1) are sufficient to document individual basin flow regimes and potential inter-basin air exchanges.

Ambient temperature and relative humidity sensors are located at the 3-m level. A total of 30-40 MEDA stations are located on or around the NTS (see Figure F.1) to ensure that meteorological conditions are thoroughly documented for the complex terrain environment found on the NTS.

Wind direction is measured to two degrees of azimuth and wind speed is accurate to $0.85 \mathrm{mph}$. Wind data are collected as 5 minute averages and are transmitted via microwave to a central processor every 15 minutes. These data are checked operationally by the duty forecaster and quality control is assured by the ARL/SORD climatologist. Plotted wind products are generated every 15 minutes for operational use. The data are stored and archived for climatological purposes.

MEDA temperature is accurate to $1^{\circ} \mathrm{F}$ between $0^{\circ} \mathrm{F}$ and $110^{\circ} \mathrm{F}$ (absolute range for the NTS is $-20^{\circ} \mathrm{F}$ to $115^{\circ} \mathrm{F}$ ). Temperature measurements are instantaneous and are taken every 15 minutes at all MEDA stations. These data are also transmitted via microwave to a computer for processing, display, and archiving.

To utilize the most representative meteorological data available for NTS sources, cloud observations from DRA were melded with the concomitant MEDA winds from Mercury and Pahute Mesa. Similarly, the cloud observations from UCC were melded with MEDA wind data from Yucca and Frenchman Flats. The straight-line distance from DRA to Mercury is 3 miles; from UCC to Frenchman Flat, 12 miles; and from DRA to Pahute Mesa, 40 miles.

Cloud cover observations needed as input to the STAR program are available from DRA (1978-present) and from UCC (1962-1978). Based on the available data, the cloud cover climatology from DRA and UCC are quite compatible. For example, UCC experiences 192 clear days annually, while DRA has 191 days. In addition, the average annual sky cover, in tenths, from sunrise to sunset for both stations is 3.9 tenths daily. The total number of cloudy days for UCC is 81 days and 88 days for DRA, annually. Therefore, the cloud cover observations from DRA and UCC can be considered as representative for most of the NTS.

In a study of precipitation on the NTS, Quiring (1983) found that the northwest part of the NTS, including Pahute Mesa, is clearly an area of diminished precipitation for the given elevation $(6,500 \mathrm{ft})$. Furthermore, the total annual precipitation for Pahute Mesa (7.9 inches) is more compatible with that from DRA (7.6 inches) than from UCC (6.8 inches). Consequently, assuming that cloud cover is directly related to precipitation, it logically follows that the cloud cover for Pahute Mesa is better represented climatologically by the cloud observations from DRA. 


\section{CONCLUSIONS}

Based on the above considerations and on the limitations of CAP88-PC, the cloud cover data from DRA were considered to be representative of Pahute Mesa. Therefore, atmospheric soundings and cloud cover observations from DRA were melded with MEDA surface wind data from Pahute Mesa for input to the STAR program to provide the very best data for calculating transport and dispersion processes.

For sources in Yucca Flat and Frenchman Flat, the cloud cover data from UCC were considered to be the most representative. Yucca Flat and Frenchman Flat are adjoining valleys of similar soil and vegetation types and similar meteorological and climatological conditions.

For sources at Mercury, the cloud observations from DRA are representative. DRA is only three miles from Mercury.

The STAR file is a matrix that includes 6 Pasquill stability categories (A through F), 6 wind speed categories, and 16 wind sectors from wind roses calculated for each specified MEDA station on the NTS. Although no weather data during the year 2001 were used in creating the STAR file for CAP88-PC calculations, the data used over the period 1983 to 1995 is considered representative. 


\section{APPENDIX G}

\section{SUPPLEMENTAL INFORMATION \\ COMPARISON WITH PREVIOUS YEARS' DATA}

$\begin{array}{ll}\text { Maximum Potential Individual EDE: } & 2001-1.7 \times 10^{-1} \mathrm{mrem}(1.7 \mathrm{i} \mathrm{Sv}) \\ & 2000-1.7 \times 10^{-1} \mathrm{mrem}(1.7 \mathrm{i} \mathrm{Sv}) \\ & 1999-1.2 \times 10^{-1} \mathrm{mrem}(1.2 \mathrm{i} \mathrm{Sv}) \\ & 1998-9.2 \times 10^{-2} \mathrm{mrem}(0.9 \mathrm{i} \mathrm{Sv}) \\ & 1997-9.0 \times 10^{-2} \mathrm{mrem}(0.9 \mathrm{i} \mathrm{Sv}) \\ & 1996-1.1 \times 10^{-1} \mathrm{mrem}(1.1 \mathrm{i} \mathrm{Sv}) \\ & 1995-1.8 \times 10^{-1} \mathrm{mrem}(1.8 \mathrm{i} \mathrm{Sv}) \\ & 1994-1.5 \times 10^{-1} \mathrm{mrem}(1.5 \mathrm{i} \mathrm{Sv}) \\ & 1993-3.8 \times 10^{-3} \mathrm{mrem}(38.0 \mathrm{nSv}) \\ & 1992-1.2 \times 10^{-2} \mathrm{mrem}(0.12 \mathrm{i} \mathrm{Sv})\end{array}$

In 1993, tunnel effluents began decreasing because of sealing the tunnel drainage systems. In 1994, re-suspension of plutonium from surface deposits was calculated. The 1996 decrease is due to decreased emissions and cleanup of areas. The 1997 decrease was due to decreased emissions, cleanup of areas, and a slight population decrease. The small increase for 1998 is due to increased emissions of tritium, and, for 1999, the increase is due to the inclusion of ${ }^{241} \mathrm{Am}$. Finally, the increase for 2000 was due to the addition of NTS areas not previously included in the re-suspension calculations.

\section{COLLECTIVE EFFECTIVE DOSE EQUIVALENT}

The maximum potential collective EDE to the 38,403 people who live within $80 \mathrm{~km}$ of the NTS emission sources was 0.44 person-rem in 2001(see Table G.1), due mostly to calculated resuspended plutonium and americium exposure. The collective EDE data are based on distance and direction from each of the sources of emission on the NTS to nearby areas. These data are displayed in the last column of Table 5.0. The collective EDE is the sum of the EDEs to the community from each emission source multiplied by the population of the community.

Table G.1 presents the portion of the cumulative population radiation dose contributed by each area from tritium, americium, and plutonium combined.

Table G.1 The Maximum Collective EDE to the Population Within $80 \mathrm{~km}$ of the NTS

\begin{tabular}{|c|c|c|c|}
\hline Area & Person-mrem/yr & Area & Person-mrem/yr \\
\hline 1 & 11.9 & 11 & 20.2 \\
\hline 2 & 11.0 & 12 & 3.0 \\
\hline 3 & 23.7 & 13 & 1.9 \\
\hline 4 & 29.4 & 15 & 26.9 \\
\hline 5 & 15.2 & 16 & 3.4 \\
\hline 6 & 6.4 & 17 & 10.6 \\
\hline 7 & 7.3 & 18 & 50.1 \\
\hline 8 & 52.2 & 19 & 29.6 \\
\hline 9 & 37.0 & 20 & 17.3 \\
\hline \multirow[t]{2}{*}{10} & 55.5 & 30 & 10.7 \\
\hline & & 52 & 15.8 \\
\hline
\end{tabular}




\section{COMPLIANCE WITH NESHAPS}

NNSA/NV was in compliance with Title 40 CFR 61, Subpart $\mathrm{H}$, during CY 2001. The methods used to assess the maximum potential offsite radiation doses are explained in Appendices $A$ through $\mathrm{E}$. These measurements and analyses are the methods of determining NTS emissions presented in the April 24, 1991, meeting between Region 9 and NNSA/NV and revised with the approval of the EPA (EPA 2001b) to allow the use of air sampling at onsite locations that would represent offsite critical receptors.

\section{COMPLIANCE WITH SUBPARTS Q AND T, Title 40 CFR 61}

The NTS is regulated by Subpart $\mathrm{H}$ (National Emission Standards for Emissions of Radionuclides Other Than Radon from DOE Facilities), but not Q (National Emission Standards for Radon Emissions from DOE Facilities) and T (National Emission Standards for Radon Emissions from the Disposal of Uranium Mill Tailings). However, BN includes Subpart Q in its Work Smart Standards. Therefore, radon flux measurements were made during this report period at the Area 3 RWMS and the Area 5 RWMS to confirm inventory records that only trace amounts of radium were disposed of in these areas and to make sure that the radon fluxes are well below the standard of $20 \mathrm{pCi} / \mathrm{m}^{2} / \mathrm{s}$ required by Subpart $\mathrm{Q}$ in the event that by-product material as defined by section 11.e(2) of the Atomic Energy Act of 1954 (as amended) is disposed of in these areas in the future. The results of the most recent study (DOE 2001a) showed that the airborne concentrations of radon and the flux measurements of radon were both at background levels. An assessment of the potential risks posed by the RWMS-5 to the public projected that the in-growth

of ${ }^{222} \mathrm{Rn}$ from the decay of ${ }^{230} \mathrm{Th}$ in thorium wastes would not exceed the standard for approximately 30,000 years (Shott et al., 1998).

\section{RADON EMISSIONS FROM ${ }^{238} \mathrm{U}$ AND ${ }^{232}$ Th SOURCES}

In the past, material from Mound Applied Technologies containing these sources was stored in cargo containers at the RWMS-5. However, since the shipment of these containers offsite in 1997 , none of these sources are present at the NTS.

\section{NON-DISPOSAL/NON-STORAGE SOURCES OF RADON EMISSION}

None of these sources exist on the NTS.

\section{QUALITY ASSURANCE PROGRAM NESHAP}

The quality assurance program for samples collected and analyzed for NESHAP is documented in an environmental monitoring plan (DOE 1998). The applicable requirements of CFR 61, Appendix B, Method 114, "Test Methods for Measuring Radionuclide Emissions from Stationary Sources" (EPA 2001b) and the requirements of DOE Order 414.1A, "Quality Assurance" (DOE 2001b) have been implemented in this plan. 


\section{APPENDIX H}

\section{REFERENCES}

Code of Federal Regulations, 2002, National Emission Standards for Hazardous Air Pollutants: Radionuclides, Title 40 CFR Part 61, U.S. Environmental Protection Agency, Washington, DC.

DOE, see U.S. Department of Energy.

Energy Research and Development Administration, 1977, Final Environmental Impact Statement, Nevada Test Site, Nye County, Nevada, Report ERDA-1551, Washington, DC.

EPA, see U.S. Environmental Protection Agency.

Federal Facilities Agreement and Consent Order (FFACO), 1996, An FFACO among the State of Nevada, the U.S. Department of Energy, and the U.S. Department of Defense, May 1996.

International Commission on Radiological Protection (ICRP), 1990, Limits for Intake by Workers, ICRP Publication 30, Supplement to Part 1, Pergamon Press, New York.

NRC, see U.S. Nuclear Regulatory Commission.

Quiring, R.F., 1983, "Precipitation Climatology for the NTS," NOAA Weather Service Nuclear Service Office (WSNSO), WSNSO351-88, Las Vegas, NV.

Shott, G. J., L. E. Barker, S. E. Rawlinson, M. J. Sully, and B. A. Moore, 1998, Performance Assessment for the Area5 RWMS at the NTS, Nye County, Nevada, Revision 2.1, Report DOE/NV/11718--176 Bechtel Nevada, Las Vegas, Nevada.

U.S. Department of Energy, 1991, Radionuclides in Surface Soil at the Nevada Test Site, Report DOE/NV/10485--02, Water Resources Center, Desert Research Institute, University of Nevada System, Las Vegas, NV.

U.S. Department of Energy, 1992, Summary of the Nevada Applied Ecology Group and Correlative Programs, Report DOE/NV--357, Ratheon Services Nevada, Las Vegas, NV.

U.S. Department of Energy, 1996a, Final Environmental Impact Statement for the Nevada Test Site and Off-Site Locations in the State of Nevada, Report DOE/EIS 0243 Nevada Operations Office, Las Vegas, NV.

U.S. Department of Energy, 1996b, National Emission Standards for Hazardous Air Pollutants Submittal - 1995, Report DOE/NV/11718--032, Bechtel Nevada, Las Vegas, NV.

U.S. Department of Energy, 1997a, Nevada Environmental Restoration Project, Double Tracks Closure Report, Report DOE/NV/11718--113, UC-802, Bechtel Nevada, Las Vegas, NV. 
U.S. Department of Energy, 1997b, Nevada Environmental Restoration Project, Clean Slate I Closure Report, Report DOE/NV/11718--159, UC-702, Bechtel Nevada, Las Vegas, NV.

U.S. Department of Energy, 1998, "Routine Radiological Environmental Monitoring Plan," Report DOE/NV/11718--244, Bechtel Nevada, Las Vegas, NV.

U.S. Department of Energy, 2000, "United States Nuclear Tests: July 1945 through September 1992, Report DOE/NV--209 (Revision 15), Nevada Operations Office, Las Vegas, NV.

U.S. Department of Energy, 2001a, Nevada Test Site 2000 Waste Management Monitoring Report, Area 3 and Area 5 Radioactive Waste Management Sites, Report DOE/NV/11718--582, Nevada Operations Office, Las Vegas, NV.

U. S. Department of Energy, 2001b, "Quality Assurance", DOE Order 414.1A, Washington, D. C., September 29, 1999.

U.S. Environmental Protection Agency, 1992, User's Guide for CAP88-PC, Version 1.0, Report 402-B-92-001, Office of Radiation Programs, Las Vegas, NV.

U. S. Environmental Protection Agency, 2001a, Letter to Kenneth A. Hoar, Director, Environmental, Safety \& Health Division, National Nuclear Security Administration, Las Vegas, Nevada from Jack P. Broadbent, Director, Air Division, Environmental Protection Agency, San Francisco, California, dated July 23, 2001.

U. S. Environmental Protection Agency, 2001b, "Test Methods for Measuring Radionuclide Emissions from Stationary Sources", Title 10 Code of Regulations, Part 61, Appendix B, Method 114, July 1, 2001 Edition.

U.S. Nuclear Regulatory Commission, 1983, Radiological Assessment," Report NUREG/CR-3332, J.E. Till and H.R. Meyer Editors, Office of Nuclear Reactor Regulation, Washington, DC. 


\section{APPENDIX I}

\section{DISTRIBUTION LIST}

K. P. Webb, Office of Primaries and Test Readiness, (DP-132 GTN), U.S. Department of Energy,19901 Germantown Road, Germantown, MD 20545

D. M. Miotla, Office of Facilities Management, (DP-17 GTN), U.S. Department of Energy, 19901 Germantown Road, Germantown, MD 20545

R. P. Berube, Acting Director, Office of Environmental Policy and Assistance, (EH-41 FORS), U.S. Department of Energy, 1000 Independence Avenue SW, Washington, DC 20585

R. L. Natoli, Office of Environmental Policy and Assistance, (EH-412 FORS), U.S. Department of Energy, 1000 Independence Avenue SW, Washington, DC 20585

G. Vazquez, Office of Environmental Policy and Assistance, (EH-412 FORS), U.S. Department of Energy, 1000 Independence Avenue SW, Washington, DC 20585 (3)

R. Anderson, Program Manager, Office of Radiation and Indoor Air, U.S. Environmental Protection Agency, 1200 Pennsylvania Avenue NW, Washington, DC 20460

D. P. Howekamp, Director, Air Division, Region 9, U.S. Environmental Protection Agency, 75 Hawthorne Street, San Francisco, CA 94103

S. Rosenblum, Air Division, Region 9, U.S. Environmental Protection Agency, 75 Hawthorne Street, San Francisco, CA 94103

T. Wallace, Assistant Manager for Technical Services, Nevada Operations Office, National Nuclear Security Administration U.S. Department of Energy, P. O. Box 98518, Las Vegas, NV 89193-8518, M/S 505

D. D. Monette, Assistant Manager for National Security, Nevada Operations Office, National Nuclear Security Administration, U.S. Department of Energy, P. O. Box 98518, Las Vegas, NV 89193-8518, M/S 505

C. P. Gertz, Assistant Manager for Environmental Management, Nevada Operations Office, National Nuclear Security Administration, U.S. Department of Energy, P. O. Box 98518, Las Vegas, NV 89193-8518, M/S 505

K. A. Hoar, Director, Environment, Safety \& Health Division, Nevada Operations Office, National Nuclear Security Administration, U.S. Department of Energy, P. O. Box 98518, Las Vegas, NV 89193-8518, M/S 505 (3)

R. C. Wycoff, Director, Environmental Restoration Division, Nevada Operations Office, National Nuclear Security Administration, U.S. Department of Energy, P. O. Box 98518, Las Vegas, NV 89193-8518, M/S 505 
E. F. DiSanza, Director, Waste Management Division, Nevada Operations Office, National Nuclear Security Administration, U.S. Department of Energy, P. O. Box 98518, Las Vegas, NV 89193-8518, M/S 505 (3)

B. Hurley, Environment, Safety \& Health Division, Nevada Operations Office, National Nuclear Security Administration, U.S. Department of Energy, P. O. Box 98518, Las Vegas, NV 89193-8518, M/S 505

Office of Scientific and Technical Information, U.S. Department of Energy, P. O. Box 62, Oak Ridge, TN 37831 (1 - electronic)

Technical Library, Nevada Operations Office, National Nuclear Security Administration, U.S. Department of Energy, P. O. Box 98518, Las Vegas, NV 89193-8518, M/S 505

G. Dempsey, Director, Center for Environmental Restoration, Monitoring \& Emergency Response, U.S. Environmental Protection Agency, P. O. Box 93478, Las Vegas, NV 89193-3478, M/S 513

D. A. Bedsun, Bechtel Nevada, P. O. Box 98521, Las Vegas, NV 89193-8521, NLV101

S. Marshall, Chief, Radiological Health Section, Bureau of Health Protection Services, 1179 Fairview Drive, Suite 201, Carson City, NV 89701-5405

E. A. Tinney, Bureau of Health Protection Services, 1179 Fairview Drive, Suite 201, Carson City, NV 89701-5405

P. J. Liebendorfer, Nevada Division of Environmental Protection, 333 W. Nye Lane, Carson City, NV 89706-0866

M. D. McKinnon, Bechtel Nevada, P. O. Box 98521, Las Vegas, NV 89193-8521, NLV083

L. Franks, Bureau of Health Protection Services, 620 Belrose Street, Las Vegas, NV 89158-5242

L. W. Nattrass, Lawrence Livermore National Laboratory, P. O. Box 808, Livermore, CA 94550-9234, M/S L-149

P. S. Raglin, Sandia National Laboratories, P. O. Box 5800, Albuquerque, NM 87185-0136

J. M. McAfee, Los Alamos National Laboratory, M/S D420, Los Alamos, NM 87545

T. W. Mulkey, Environmental Operations, Bechtel Nevada, P. O. Box 98521, Las Vegas, NV 89193-8521, M/S NTS110

Public Reading Facility, Nevada Operations Office, National Nuclear Security Administration, U.S. Department of Energy, P. O. Box 98521, Las Vegas, NV 89193-8521, M/S NLV040 
